\title{
ĐẠC TRƯNG DI TÍCH VÀ DI VẠT TẠI CÁC DI TÍCH CÔNG XƯ ỞNG CHẾ TÁC ĐỒ ĐÁ THỜI TIỀN SỬ Ở TÂY NGUYÊN
}

\author{
Lê Xuân Hưng ${ }^{a^{*}}$
}

${ }^{a}$ Khoa Lịch sủ, Truoòng Đại học Đà Lạt, Lâm Đồng, Việt Nam

"Tác giả liên hệ: Email: hunglx@dlu.edu.vn

Lịch sử bài báo

Nhận ngày 15 tháng 01 năm 2020

Chỉnh sửa ngày 08 tháng 02 năm 2020 | Chấp nhận đăng ngày 19 tháng 02 năm 2020

\section{Tóm tắt}

Bài báo nghiên cứu các hoạt động thủ công chế tác công cu đá, một ngành sản xuất quan trọng trong co cấu kinh tế - xã họi tiền sủ ở Tây Nguyên giai đoạn 4,000BP (Before Present). Dưa vào tu liệu 50 di tích công xuớng giai đoạn hậu kỳ Đá mới được phát hiện ở các tỉnh Gia Lai, Đắk Lắk, Đắk Nông, và Lâm Đồng, bài báo đã xác định được sụ tồn tại của bốn trung tâm công xưởng chế tác đá. Trong mối trung tâm có các quy trình khai thác và chế tác công cu lao động tù các loại đá khác nhau, tạo ra các loại hình sản phẩm khác nhau, và có phạm vi sử dụng không giống nhau ở Tây Nguyên. Sụ ra ra đời của các di tích công xưởng này không chỉ ghi nhận rằng cu dân hậu kỳ Đá mói ở Tây Nguyên đã ở trình độ chuyên hóa cao và có sự phân công lao động trong sản xuất, mà các sản phẩm công xưởng đã được luu thông trên địa bàn và tạo ra sụ phát triển tuơng đối đồng đều trên toàn khu vục Tây Nguyên, đấy là tiền đề quan trọng nảy sinh thời đại Kim khí ở vùng đất này.

Từ khóa: Công xưởng chế tác đá; Đá mới; Phân công lao động; Tiền sử Tây Nguyên.

DOI: http://dx.doi.org/10.37569/DalatUniversity.10.1.644(2020)

Loại bài báo: Bài báo nghiên cứu gốc có bình duyệt

Bản quyền @ 2020 (Các) Tác giả.

Cấp phép: Bài báo này được cấp phép theo CC BY-NC 4.0 


\title{
CHARACTERISTICS OF RELICS AND ARTIFACTS AT STONE-TOOL-CRAFTING WORKSHOP RELICS IN THE PREHISTORIC PERIOD IN THE CENTRAL HIGHLANDS
}

\author{
Le Xuan Hung ${ }^{\mathrm{a}^{*}}$ \\ ${ }^{a}$ The Faculty of History, Dalat University, Lamdong, Vietnam \\ ${ }^{*}$ Corresponding author: Email: hunglx@dlu.edu.vn
}

Article history

Received: January $15^{\text {th }}, 2020$

Received in revised form: February $8^{\text {th }}, 2020 \mid$ Accepted: February $19^{\text {th }}, 2020$

\begin{abstract}
This paper investigates the crafting activities of stone-tool-making, an essential manufacturing industry in prehistoric socio-economic structure in the Central Highlands from 4,000BP. Based on the data of 50 workshop relics of the post-Neolithic period discovered in Gialai, Daklak, Daknong, and Lamdong provinces, the article identifies the existence of four stone-tool-making centers. In each center, the quarrying process and the types of stones used for machining are different. This creates different types of products and the scope of using stone-tool models is, therefore, varied in the Central Highlands. The existence of these factory relics not only proves the post-Neolithic inhabitants in the Central Highlands were highly specialized but had a deep division of labor in production. The circulation of products created a relatively similar development throughout the Central Highlands, which is a critical premise for the emergence of the Metal Age in this region.
\end{abstract}

Keywords: Division of labor; Neolithic; Prehistory of Central Highlands; Stone-toolcrafting workshop.

DOI: http://dx.doi.org/10.37569/DalatUniversity.10.1.644(2020)

Article type: (peer-reviewed) Full-length research article

Copyright @ 2020 The author(s).

Licensing: This article is licensed under a CC BY-NC 4.0 


\section{MỞ ĐẦU}

Đến nay, trên vùng đất Tây Nguyên, giai đoạn tiền sử đã phát hiện gần 50 di tích công xưởng chế tác đồ đá, được phân bố trong mối quan hệ chặt chẽ với địa hình và hệ thống thủy văn. Các di tích này có sự tách biệt tương đối rõ đối với những địa điểm thuần cư trú về tính chất và quy mô. Tuy nhiên, trong phần lớn các di tích công xưởng vẫn tồn tại những di tồn văn hoá liên quan đến hoạt động cư trú nhưng có mức độ đậm nhạt khác nhau. Sự đa dạng về loại hình di tích ở Tây Nguyên được thể hiện qua các loại hình di chỉ, như: Thuần cư trú, thuần mộ táng, và cư trú - mộ táng; Công xưởng, cư trú - xưởng, và cư trú - xưởng - mộ táng. Các di tích cư trú thường phân bố xung quanh khu vực công xưởng, những di tích này hình thành hệ thống dạng làng cổ và đã tạo nên những nét văn hoá đặc trưng cho từng hệ thống.

Dựa trên những kết quả điều tra, thám sát, khai quật,cũng như ứng dụng các phương pháp của khoa học tự nhiên để xác định nguồn gốc nguyên liệu và công cụ đá, bài viết phác thảo lên diện mạo của các di tích công xưởng từ quy trình chế tác công cụ, các sản phẩm đặc trưng, và mối quan hệ của các di tích công xưởng trong không gian tiền sử Tây Nguyên. Theo đó, nêu rõ đặc trưng của các trung tâm/nhóm di tích công xưởng, như: Trung tâm công xưởng H'lang chuyên chế tạo rìu bôn vai xuôi bằng đá opal; Trung tâm Ia Mơr - Làng Krông chuyên chế tạo rìu vai xuôi và bôn răng trâu chủ yếu bằng đá phtanite, ít đá opal và silic; Trung tâm Chư K'tur - Taipêr chuyên chế tác rìu bôn có vai, rìu thắt eo bằng đá opal; và Trung tâm Thôn Bốn - Hoàn Kiếm chuyên chế tạo rìu và bôn hình tứ giác là nội dung cơ bản của bài báo này.

\section{2. ĐẶC TRƯNG DI TÍCH}

\section{1. Đặc trưng phân bố di tích}

Ở Tây Nguyên, với đặc điểm là có đường phân thuỷ chảy theo hai hướng tây và đông, đa số các sông ngòi đổ về sườn tây và thuộc hệ thống sông Mê Kông. Phía đông Tây Nguyên chỉ có duy nhất sông Ba và các chi lưu đổ về phía đông qua cửa Tuy Hòa rồi chảy ra biển Đông. Trong gần 50 di tích công xưởng hiện biết, các di tích này phân bố thành một số trung tâm hay nhóm di tích, mỗi nhóm tương ứng với một trong 21 vùng tiểu vùng địa lý nhất định theo cách phân chia của Nguyễn (1986) (Hình 1). Các di tích/nhóm di tích thường tập trung quanh những sông hoặc các hồ lớn như hồ Biển Hồ (Gia Lai) và hồ Lắk (Đắk Lắk) (Lê, 2015; Nguyễn, 2007; \& Vũ, Nguyễn, \& Đào, 1995).

Trong hệ thống sông Ba - một sông lớn duy nhất đổ nước ra biển Đông, có hai nguồn cung cấp nước: Một nhánh bắt nguồn từ cao nguyên Pleiku trên đất huyện Chư Sê và Chư Pứ (Gia Lai) gặp dòng chính sông Ba ở A Yunpa. Trên thượng nguồn này đã phát hiện các di chỉ như: Plei Kly Phun, Plei Chu Klan, Plei Plei, Quen Mép, Plei Grêu Bêu... Ở thượng nguồn sông Krông Năng - một nhánh lớn đổ vào sông Ba, thuộc địa phận huyện Ea Kar (Đắk Lắk) cũng đã phát hiện nhóm di tích công xưởng Chư K'tur, Thanh Sơn, và Bản Thái, các di tích này phân bố trong địa hình vùng lòng chảo hẹp bán bình nguyên xen kẽ đồi núi thấp. Ở một nhánh khác của thượng du sông Ba trên đất tỉnh Kon Tum, chảy qua các huyện K'Bang, An Khê, Đắk Pơ, và Kông Chro 
(Gia Lai) cũng đã phát hiện một số di tích công xưởng chế tác đá như: Tư Lương, Đắk Giang, Soi Tre, Làng Róh, và nhóm sáu di tích công xưởng ở xã H'lang (Kông Chro, Gia Lai).

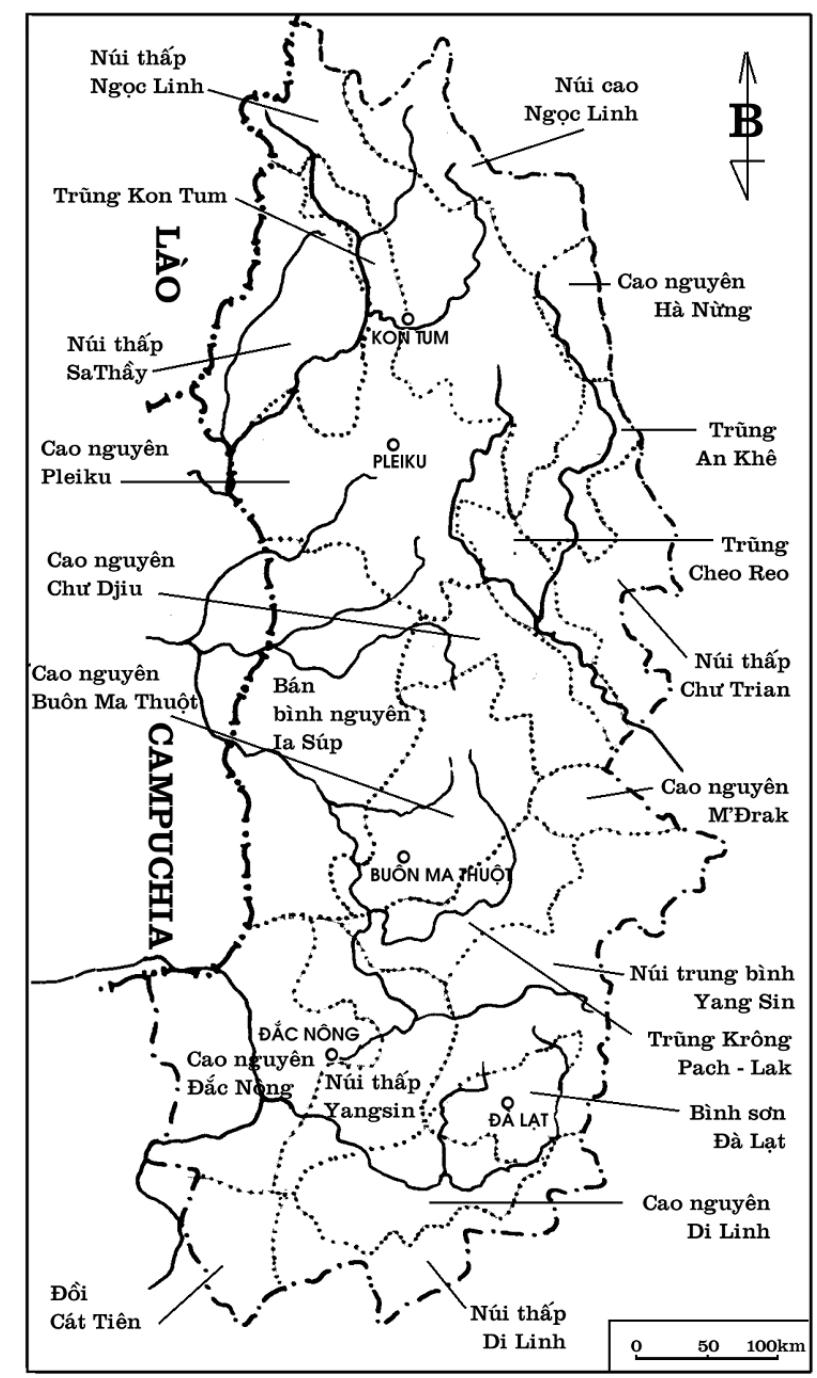

Hình 1. Các vùng địa lý của Tây Nguyên

Nguồn: Nguyễn (1986).

Các sông ở sườn tây của Tây Nguyên đều thuộc hệ thống sông Mê Kông trong tiểu vùng sông Mê Kông. Hệ thống này có ba khu vực, phân bố ở ba sông lớn, gồm: Sông Sê San với ba phụ lưu là sông Krông Pôkô, sông Đăk Bla, và sông Sa Thầy, phân bố chính trên vùng trũng Kon Tum và núi thấp Sa Thầy (Kon Tum); Hệ thống sông Ia Đrăng gồm các sông Ia Đrăng, sông Ia Lốp, và Ia Mơr, phân bố chủ yếu trên cao nguyên Pleiku (Gia Lai); và Hệ thống sông Srêpốk gồm các phụ lưu: Sông Krông Ana, Krông Nô, và $\mathrm{Ea} \mathrm{H}^{\prime} l e o$, phân bố trên cao nguyên Mơ Nông và vùng trũng Krông Pách Lắk (Đắk Lắk và Đắk Nông). Hệ thống sông Đồng Nai có sông Đạ Đờn ở vùng đồi thấp Lâm Hà và Cát Tiên (Lâm Đồng). 
- Trong hệ thống sông Sê San đã phát hiện được gần 70 di tích tiền sử các loại, tập trung nhất là ở vũng trũng Kon Tum và vùng núi cao $S a$ Thầy. Trong khu vực này chưa tìm thấy các di tích công xưởng chế tác rìu đá nào thực sự (Nguyễn \& Phan, 2015). Ở một số di tích có dấu vết chế tác công cụ đá nhưng rất mờ nhạt và khó xác định. Phần lớn các di tồn văn hóa khác ở đây liên quan trực tiếp hoạt động cư trú, cư trú - mộ táng của cư dân tiền sử;

- Trong hệ thống sông Ia Đrăng đã phát hiện trên 50 di tích giai đoạn tiền sử, trong đó có những di tích công xưởng chế tác rìu đá như: Thôn Bảy, Taipêr, Ia Mơr, Làng Krông (cũ), Suối Bích, Suối Đội Bảy, Ia Bòong, và mới đây là di tích công xưởng chế tác bôn hình răng trâu B'riêng ở xã Ia Boòng (Chư Prông, Gia Lai);

- Trong hệ thống sông Srêpôk đã phát hiện được hơn 30 địa điểm khảo cổ học tiền sử, trong đó có một số công xưởng chế tác rìu đá. Cụ thể, một nhánh hợp lưu của Ia H'leo và Ia Súp (Đắk Lắk) đã phát hiện công xưởng Tsham A. Cũng như vậy, các di tích công xưởng chế tác công cụ đá ở Đắk Nông cũng có đặc điểm phân bố tương đồng như các di tích khác ở Tây Nguyên. Với nhóm di tích ở Thôn Bảy, Thôn Tám hay các địa điểm ở đầm Sương Mù, các di tích công xưởng chế tác công cụ đá phân bố trên những triền đồi thấp và có hệ thống suối Đắk Rít và Đắk Mao, là các chi lưu của sông Srêpôk, với nguồn nguyên liệu đá dồi dào và điều kiện tự nhiên thuận lợi cho việc cư trú và tổ chức các hoạt động sản xuất. Hay, cụm công xưởng Suối Bốn và các di tích tiền sử khác trên địa bàn Đắk R'lấp cũng phân bố dựa trên hệ thống suối Đắk Bukso và suối Đắk R'lấp, là chi lưu đổ nước vào hệ thống sông Đồng Nai ở thượng nguồn.

Các di tích công xưởng ở Lâm Đồng thì phân bố thành cụm khá tập trung. Mỗi cụm có từ ba đến năm địa điểm nằm trong các khúc lượn cong hình sin của những con suối lớn trong bồn địa thung lũng xã Gia Lâm, Nam Hà, và Phúc Hưng (huyện Lâm Hà), đây là những chi lưu đổ nước vào dòng Đạ Đờn. Đáng chú ý là các khúc uốn lượn của những con sông và suối này chính là nơi lấy nước sinh hoạt, tránh gió, ngăn thú dữ, chuyên chở nguyên liệu và sản phẩm công xưởng, hay đánh bắt thủy sinh. Cũng chính các đoạn uốn khúc này là những con hào tự nhiên bao lấy nơi cư trú và ngăn cách điểm cư trú này với điểm cư trú khác tạo nên "làng phòng thủ" một cách tự nhiên (Trần, 2007 , tr. 41). Cách kết cấu "làng" kiểu này chưa thấy trong các di tích tiền sử ở Tây Nguyên nói riêng và Việt Nam nói chung.

Tóm lại, một trong những đặc trưng phân bố các di tích tiền sử Tây Nguyên nói chung và công xưởng nói riêng là gắn liền với những vùng đất có điều kiện thuỷ văn thuận lợi. Tây nguyên có địa hình và địa mạo phù hợp cho việc cư trú và các hoạt động nông nghiệp, cũng như có nguồn nguyên liệu đá phong phú và tương thích với nguyên liệu đá chế tác công cụ lao động.

Trong các di tích công xưởng thường tồn tại các yếu tố cư trú nhưng có mức độ đậm nhạt khác nhau. Hay, trong một số địa điểm cư trú vẫn duy trì việc tái chế công cụ 
đá, đặc biệt là những công cụ được chế tác từ đá opal hay silic. Cũng như vậy, sự tách biệt cũng khá rõ giữa di tích cư trú với di tích cư trú - mộ táng như đã thấy trong văn hoá Lung Leng hay Biển Hồ.

Phạm vi phân bố của mỗi di tích công xưởng có quy mô lớn nhỏ khác nhau, một số địa điểm tập trung thành nhóm hay trung tâm với quy mô lớn nhỏ không giống nhau, nguyên liệu chế tác và sản phẩm chế tạo ra cũng khác nhau. Trong một số trung tâm công xưởng đã ghi nhận rõ quy trình chế tạo công cụ đá, mà ở đó, mỗi di tích đảm nhận một hoặc hai công đoạn trong quy trình chế tạo rìu đá. Quy mô của một số di tích lớn lên tới $20,000 \mathrm{~m}^{2}$ như Bản Thái (Đắk Lắk) và Thôn Tám (Đắk Nông), hay di tích Chư K'tur $\left(10,000 \mathrm{~m}^{2}\right)$, Thôn Bốn $\left(16,000 \mathrm{~m}^{2}\right)$, Phúc Hưng $\left(15,000 \mathrm{~m}^{2}\right)$, Taipêr $\left(15,000 \mathrm{~m}^{2}\right)$, H'lang $1\left(10,000 \mathrm{~m}^{2}\right)$, và $\mathrm{B}$ 'riêng $\left(15,000 \mathrm{~m}^{2}\right)$ (Lê, 2015). Ở những địa điểm này thường có số lượng hiện vật nhiều với loại hình phong phú. Các chế phẩm còn lại nơi công xưởng là những phác vật bị lỗi kỹ thuật nào đấy, khối lượng phế phẩm như mảnh tước, và phiến tước chiếm áp đảo trong toàn sưu tập, đá nguyên liệu và hạch đá nhiều, thời gian tồn tại của di tích lâu dài. Những di tích nhỏ có khi chỉ khoảng trên dưới $1,000 \mathrm{~m}^{2}$, như Thôn Bốn 1, Thôn Bốn 2, Thôn Bốn 4 (Lâm Đồng), Tsham A (Đắk Lắk), hay Làng Krông và Suối Đội 7 (Gia Lai), nhưng trung bình các công xưởng thường có diện tích từ 2,000 đến $6,000 \mathrm{~m}^{2}$ (Lê, 2015). Cần nhấn mạnh rằng, thông thường, trong một nhóm hay trung tâm di tích, thì địa điểm có diện tích lớn thường nằm ở giữa (trung tâm), các di tích nhỏ hơn phân bố chung quanh và đảm nhận một hoặc hai công đoạn tiếp theo của quy trình chế tác rìu và bôn đá.

Tư liệu cho biết, ngay từ khi công xưởng ra đời, các di tích công xưởng đã có sự chuyên hoá hết sức rõ rệt, như: Khai thác nguyên liệu và các công đoạn chế tác sản phẩm trong trung tâm hay giữa các trung tâm với nhau. Có thể chỉ ra trong các trung tâm và nhóm công xưởng dưới đây:

- Trung tâm công xưởng Chư K'tur - Taipêr chuyên chế tạo rìu có vai, một ít loại có hình tứ giác, và nguyên liệu chế tác chủ yếu từ đá opal và chỉ ít đá silic. Trung tâm này có phạm vi ảnh hưởng tương đối rộng với phạm vi ảnh hưởng là vùng sông Krông Hnang, sông $\mathrm{Ba}$, và phía sườn đông của Tây Nguyên. Đây là địa bàn cư trú chủ yếu của người Jrai Chor trước đây;

- Trung tâm Ia Mơr - Làng Krông (cũ) chuyên chế tạo rìu có vai với ít bôn răng trâu từ đá phtanite, opal, và một số từ đá silic. Phạm vi phân bố của trung tâm này, trước đây, là địa bàn cư trú chủ yếu là người Jrai Chor và số ít người Jrai Hdrung;

- Trung tâm H'lang gồm các di tích công xưởng phân bố trên địa bàn các huyện K'Bang, Đắk Pơ, và Kông Chro (Gia Lai). Đặc trưng hiện vật ở đây là chế tác rìu có vai bằng đá opal. Trong địa bàn trên, phân bố đậm đặc rìu có vai bằng đá opal là ở Kong Chro và thượng lưu sông $\mathrm{Ba}$, cũng là địa bàn phân bố chính của người $\mathrm{Ba} \mathrm{Na}$, những người nói ngôn ngữ Môn-Khmer; 
- Các công xưởng chế tác rìu bầu dục được tìm thấy ở Thôn Tám và một số di chỉ ở quanh đầm Sương Mù ở xã Đắk Wil (Cư Jút, Đắk Nông), Buôn Kiều ở xã Yang Mao (Krông Bông, Đắk Lắk), và các di tích ở làng Gà và xã Ia Boòng (Chư Prông, Gia Lai). Gần đây còn phát hiện thêm các địa điểm như: Buôn Hằng $1 \mathrm{C}$ ở xã Ea Uy (Krông Pắk, Đắk Lắk) (Phạm, Trương, \& Lê, 2019) và hang núi lửa C6-1 và các địa điểm tiền sử ngoài trời ở Krông Nô (Đắk Nông) (Lê, La, Phạm, Vũ, \& Nguyễn, 2018; Lê, Nguyễn, \& Đoàn, 2019; Lê, Phạm, \& Nguyễn, 2019; \&Nguyễn, Lê, \& Nguyễn, 2019). Đặc trưng nhất ở các di tích này là chuyên chế tác rìu hình bầu dục, công cụ hình đĩa, và rìu mài lưỡi từ đá chert, schiste silic, và basalt. Phạm vi ảnh hưởng hiện biết của di tích không lớn lắm;

- Nhóm di tích công xưởng Suối Bốn, xã Nhân Đạo (Đắk R'lấp, Đắk Nông) đã phát hiện được năm địa điểm, tuy chưa phát hiện được các chế phẩm nhưng số lượng mảnh tước tìm thấy nhiều, đặc biệt là địa điểm Suối Bốn 2 và 4 , với nguyên liệu gần như tuyệt đối là đá opal.

Trên đất Kon Tum đến nay vẫn chưa có những phát hiện về hoạt động chế tạo công cụ đá. Mặc dù, ở đây đã phát hiện trên 50 địa điểm khảo cổ học thuộc giai đoạn hậu kỳ Đá mới - sơ kỳ Kim khí. Trong một vài di chỉ tiền sử ở Kon Tum đã tìm thấy mảnh tước, như di chỉ Lung Leng hay một số địa điểm trong lòng hồ Plei Krông (Nguyễn, 2005a; Nguyễn, Lê, Nguyễn, Nguyễn, \& Phan, 2014). Tuy vậy, những mảnh tước ở đây thường có kích thước nhỏ đến rất nhỏ, mật độ mảnh tước không nhiều, và trên một mặt của nhiều mảnh tước còn có dấu vết mài. Điều đó cho thấy, những mảnh tước được tách ra từ việc ghè đẽo lại lưỡi rìu chứ hoàn toàn không tìm thấy hạch đá và rất hiếm phác vật rìu. Chính vì vậy, rất khó để xác định ở đây có phải là nơi chuyên chế tác công cụ đá hay không.

\section{2. Đặc trưng địa tầng một số công xưởng tiêu biểu}

Các di tích công xưởng ở Tây Nguyên bảo lưu dấu vết chế tác công cụ đá đậm nhạt không giống nhau. Tính chất và địa tầng của các di tích dày mỏng cũng khác nhau. Kết quả một số di tích đã khai quật, một số đặc điểm đáng chú ý:

\subsubsection{Di tích Thôn Bảy}

Di tích này ở thị trấn Chư Prông, huyện Chư Prông (Gia Lai) được khai quật vào năm 2002 (Bùi \& Hà, 2002). Địa tầng dày từ $1.2 \mathrm{~m}$ đến $1.3 \mathrm{~m}$, kết cấu ba lớp như sau:

- Lớp mặt, dày từ $20 \mathrm{~cm}$ đến $40 \mathrm{~cm}$, là lớp đất canh tác bị xáo trộn với kết cấu đất đỏ basalt màu đỏ nhạt. Trong lớp mặt chứa di vật khảo cổ như gốm mảnh, công cụ đá, mảnh tước, và rễ thực vật;

- Tầng văn hoá nằm ngay dưới lớp mặt, dày từ $75 \mathrm{~cm}$ đến $95 \mathrm{~cm}$ với kết cấu đất đỏ basalt nhưng có màu đỏ sẫm hơn so với lớp mặt. Càng xuống sâu đất càng mịn, thuần, và không xốp như lớp mặt. Trong tầng văn hoá chứa nhiều 
công cụ lao động, mảnh tước, gốm tiền sử... Hố khai quật xuất lộ cụm đá nguyên liệu lớn nhỏ khác nhau và một số di tích bếp. Đáng chú ý là ở hố hai còn phát hiện bốn mộ táng;

- Sinh thổ, từ độ sâu $1.2 \mathrm{~m}$ đến $1.3 \mathrm{~m}$, là đất đỏ basalt tương đối thuần nhất. Ở lớp này không có dấu vết hoạt động của người tiền sử.

Nhìn chung, di tích Thôn Bảy chỉ có một tầng văn hoá nhưng thể hiện hai mức khác nhau (Hình 2a). Mức trên bị xáo trộn do những hoạt động canh tác của cư dân hiện đại. Mức dưới được bảo tồn khá nguyên vẹn, không bị xáo trộn, và chứa các di tồn văn hoá của cư dân tiền sử. Mức dưới của hố khai quật 2 ở di tích Thôn Bảy có sự tương đồng với hố khai quật 3 ở di tích Taipêr (Gia Lai) về đặc trưng di tích, di vật, và độ dày của tầng văn hoá. Vết tích hoạt động công xưởng ở đây gắn liền với nơi cư trú. Các hoạt động công xưởng được thể hiện rõ qua các cụm đá nguyên liệu và phế liệu tập trung cao. Ngoài ra, các khâu gia công đều có mặt ở đây, như: Ghè tạo phôi, tu sửa, mài, và hoàn thiện rìu có vai. Cũng nhấn mạnh thêm, di tích cư trú - xưởng Thôn Bảy còn có mộ táng, loại hình mộ nồi/vò.

\subsubsection{Di tích Taipêr}

Di tích Taipêr ở làng Taipêr, xã Ia Ko, huyện Chư Sê (Gia Lai) được khai quật vào năm 2002 (Nguyễn \& Phan, 2007). Kết cấu địa tầng gồm ba lớp như sau:

- Lớp mặt, dày trung bình $40 \mathrm{~cm}$, là lớp đất canh tác đã bị xáo trộn do hoạt động canh tác của cư dân hiện đại. Kết cấu là đất đỏ basalt màu nâu sẫm, khá rắn chắc, và hầu như không có di vật;

- Lớp hai là tầng văn hoá, dày trung bình $65 \mathrm{~cm}$, với kết cấu đất đỏ basalt, màu sẫm, tương đối mềm, tơi, và độ liên kết yếu, nằm ngay dưới lớp canh tác. Trong tầng văn hoá còn bảo lưu vết tích văn hoá của con người như than tro, công cụ lao động, đồ gốm, mảnh tước, bếp, và mộ táng;

- Sinh thổ là lớp đất đỏ basalt màu nâu sẫm, khá mềm, và không có dấu tích hoạt động của con người.

Di tích Taipêr chỉ có một tầng văn hoá, phát triển liên tục từ sớm đến muộn (Hình 2b). Dấu tích công xưởng thể hiện ở khối lượng lớn đá nguyên liệu đã hoặc chưa có dấu vết chế tác, rất nhiều mảnh tước, hạch đá, và phác vật rìu bôn bị gãy và bị hỏng do bị lỗi kỹ thuật nào đó không thể tiếp tục chế tác, nhiều hòn ghè, và hoàn kê đập. Những hoạt động thủ công ở đây gắn với nơi cư trú, có thể là tạm thời, bởi mới gặp có hai bếp lửa. Trong đó, bếp thứ nhẩt nằm gần sát sinh thổ, có hình gần tròn, đường kính $0.9 \mathrm{~m}$, đất màu hơi đỏ, cứng, và có vết than tro. Trong bếp có tám viên đá basalt, trung tâm bếp có hai rìu có vai, hai bàn mài, nhiều mảnh gốm thô, và một số mảnh rìu và mảnh tước. Bếp thứ hai nằm ở đáy lớp hai, có độ sâu khoảng $70 \mathrm{~cm}$ so với mặt đất, bếp có hình gần bầu dục (dài $2 \mathrm{~m}$ và rộng $1 \mathrm{~m}$ ). Trong khu vực bếp có 10 viên đá basalt, giữa bếp có rìu vai xuôi, nhiều mảnh tước, hạch đá, bàn mài bằng gỗ hoá thạch, mảnh 
gốm,và ít than tro nằm rải rác. Bếp ở di tích Taipêr có quy mô nhỏ và chưa rõ cấu trúc phần đun nấu hay trung tâm sinh hoạt của người tiền sử (Nguyễn \& Phan, 2007, tr. 1819).

Ngoài ra, di tích Taipêr còn là nơi để mộ táng, ở đây đã phát hiện hai ngôi mộ thuộc hai táng tục khác nhau và đều liên quan đến chủ nhân di tích (chôn trực tiếp vào đất và chôn trong quan tài gốm). Các tập tục mai táng gắn liền với hoạt động thủ công chế tác đá. Trong mộ chôn theo bát bồng nhỏ, rìu, và bôn có vai đã qua sử dụng. Hiện vật chôn theo là số lẻ (một nồi gốm và bảy rìu đá có vai). Có thể đây là một nghi thức "chia của" cho người chết, là hình thức tín ngưỡng sơ khai của cư dân cổ ở đây (Nguyễn $\&$ Phan, 2007, tr. 19). Tư liệu trên cho thấy, dù công xưởng chế tác rìu và bôn đá đã ra đời nhưng một vài nơi ở Tây Nguyên, công xưởng vẫn chưa hoàn toàn tách khỏi nơi cư trú và mộ táng.

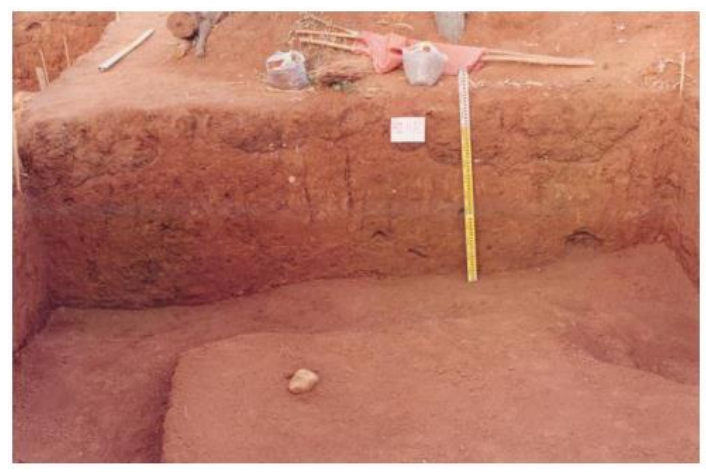

(a)

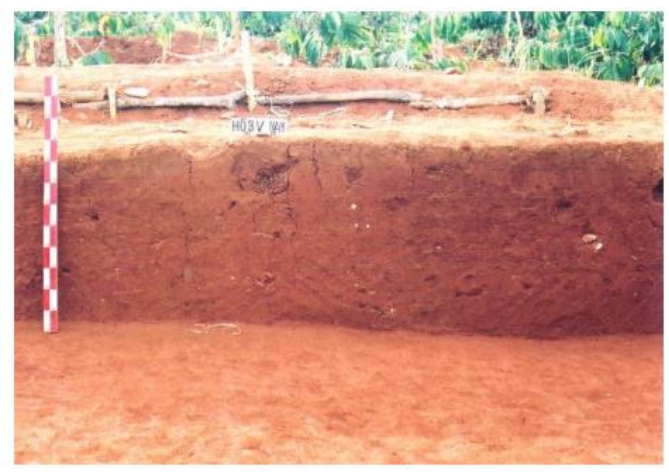

(b)

Hình 2. Địa tầng di tích Thôn Bảy và Taipêr (Gia Lai)

Ghi chú: a) là địa tầng vách Bắc, hố khai quật 2 , di tích Thôn Bảy;

b) là địa tầng vách Nam, hố khai quật 3 , di tích Taipêr.

Nguồn: Lê (2015).

\subsubsection{Di tích Làng $\mathrm{Ngol}$}

Di tích Làng Ngol ở địa phận xã Ia Grai, huyện Chư Sê (Gia Lai) được khai quậtvào năm 2003 (Bùi, Nguyễn, \& Mai, 2004). Địa tầng hai hố khai quật tương đồng nhau, dày từ $70 \mathrm{~cm}$ đến $80 \mathrm{~cm}$, gồm ba lớp như sau:

- Lớp mặt là đất đỏ basalt bị phong hoá màu nâu nhạt, dày từ $15 \mathrm{~cm}$ đến $20 \mathrm{~cm}$. Đây là lớp đất canh tác bị xáo trộn và chứa một số di vật khảo cổ;

- Lớp văn hoá, dày từ $50 \mathrm{~cm}$ đến $60 \mathrm{~cm}$, là đất đỏ basalt phong hoá màu nâu sẫm và kết cấu hơi bở rời. Trong lớp này chứa các dấu vết hoạt động sống của con người như than tro, mộ táng, các công cụ sản xuất bằng đá, và đồ gốm;

- Sinh thổ, nằm dưới lớp văn hoá, là đất đỏ basalt màu nâu sẫm, kết cấu đất yếu nên khá bở rời, thuần, và không có hiện vật khảo cổ. 
Tầng văn hoá di tích Làng Ngol khá dày, chỉ có một tầng văn hoá, và liên tục từ sớm tới muộn. Cư dân cổ sống định cư lâu dài, tại một trong những điểm cư trú có phạm vi rộng và sống tập trung thành làng mạc có quy mô khá lớn trong khu vực (Bùi, Nguyễn, \& Mai, 2004). Trong tầng văn hoá đã phát hiện được hai bếp lửa nằm ở độ sâu $50 \mathrm{~cm}$ đến $55 \mathrm{~cm}$. Bếp thứ nhất có diện tích khoảng $1 \mathrm{~m}^{2}$ và hình gần bầu dục. Khu vực giữa có một viên đá tảng bị nung đỏ, xung quanh có những mảng đất cháy đỏ lẫn than, ít mảnh tước, và gốm. Bếp thứ hai có diện tích khoảng $2 \mathrm{~m}^{2}$ và hình gần số "8". Trong bếp có dấu vết đất cháy đỏ lẫn than cháy, gốm, và mảnh tước. Trong hố khai quật còn phát hiện mộ táng, là một cụm đồ gốm có diện tích khoảng $1.5 \mathrm{~m}^{2}$. Cụm gốm này nhiều khả năng có bốn cá thể là hai vò và hai bát bồng, các đồ gốm này đều được tô đen ánh chì phía trong lòng. Trong khu vực mộ cũng lẫn khá nhiều than tro nhưng không có đất cháy. Những người khai quật cho rằng, các khu vực tập trung đồ gốm là những loại gốm như bát bồng và vò gốm tô đen ánh chì thì thường là đồ tuỳ táng chôn theo người chết (Bùi và ctg., 2004, tr. 2-3). Rất có thể đây là mộ táng của chủ nhân di tích và một cách táng thức khá phổ biến của cư dân tiền sử Tây Nguyên.

Các di tích công xưởng ở Tây Nguyên thường gần nguồn nguyên liệu đá. Với các công xưởng khai thác, sơ chế ban đầu, và ghè tu chỉnh hoàn thiện phác vật thì thường có tầng văn hóa không dày lắm, vết tích cư trú mờ nhạt, và hầu như không còn có chức năng mộ táng nữa. Đặc trưng này được Nguyễn, Nguyễn, và Lê (2008) được xem xét qua một số di tích tiêu biểu dưới đây:

\subsubsection{Di tích Ia Mor}

Di tích Ia Mơr ở thôn Klăh, xã Ia Mơr, huyện Chư Prông (Gia Lai) được khai quật vào năm 2008. Kết cấu địa tầng mỏng, gồm ba lớp từ trên xuống như sau:

- Hố khai quật một: Lớp mặt là đất sét, dày trung bình $20 \mathrm{~cm}$, đất màu trắng đục hay xám nhạt, lẫn nhiều cỏ và rễ cây, và khá cứng; Trong lớp này chứa hiện vật như mảnh tước, phác vật rìu... Lớp văn hóa dày trung bình $30 \mathrm{~cm}$, kết cấu đất sét màu nâu đỏ, đất phù sa lẫn cát, tơi, mềm, và ít mùn thực vật; Trong tầng văn hoá còn bảo lưu các di tồn của con người như phác vật rìu, rìu mài toàn thân, và đồ gốm. Sinh thổ ở độ sâu $50 \mathrm{~cm}$ trở xuống, đất nâu, dẻo, nén chặt, và khá thuần; Lớp này không có hiện vật khảo cổ;

- Hố khai quật hai: Lớp mặt bị xáo trộn, dày trung bình $25-30 \mathrm{~cm}$, kết cấu đất sét phù sa lẫn cát màu hồng nhạt, khá cứng, tương đối thuần, có nhiều rễ cây, và không có hiện vật. Tầng văn hóa dày trung bình $25-30 \mathrm{~cm}$, cấu tạo đất là phù sa lẫn cát, tơi và mềm, ít mùn thực vật, và có màu vàng nhạt; Trong tầng văn hoá tìm thấy phác vật rìu, rìu mài toàn thân, và đồ gốm. Sinh thổ ở độ sâu $60 \mathrm{~cm}$ trở xuống, đất có màu nâu, dẻo, nén chặt, và không có hiện vật.

Nhìn chung, ở cả hai hố khai quật, hiện vật xuất lộ ngay trên bề mặt. Trong tầng văn hóa ken dày mảnh tước, phiến tước, và phác vật công cụ đá, tuy nhiên, số lượng mảnh gốm thưa thớt. Cả khu $\mathrm{A}$ và $\mathrm{B}$ ở công xưởng Ia Mơr đều chưa tìm thấy đá nguyên liệu và hạch đá, cũng như chưa tìm thấy những mảnh tước ban đầu hay mảnh tước còn 
giữ lại vỏ tự nhiên. Điều này lý giải, nơi đây không phải là điểm khai thác hoặc chế tác ban đầu. Khu $\mathrm{B}$ là đồi đất tương đối dốc và bị tác động của các hoạt động canh tác của cư dân hiện đại nên tầng văn hoá bị xâm hại và rửa trôi lớp mặt. Khu A tầng văn hóa dày hơn đôi chút, được bảo tồn tốt và nguyên vẹn do chưa có sự tác động khai phá của cư dân hiện đại (Nguyễn và ctg., 2008).

\subsubsection{Di tích Chur K'tur}

Di tích này ở buôn Sê Đăng, xã Xuân Phú, huyện Ea Kar (Đắk Lắk) được khai quật vào năm 2002 , địa tầng dày trung bình $70 \mathrm{~cm}$ và lớp văn hoá dày $50 \mathrm{~cm}$ nằm ngay dưới lớp mặt dày khoảng $20 \mathrm{~cm}$ (Nguyễn, 2003) (Hình 3). Kết cấu địa tầng của hai hố như sau:

- Lớp mặt là lớp đất canh tác bị xáo trộn lẫn mùa thực vật, dày từ $10 \mathrm{~cm}$ đến $25 \mathrm{~cm}$, và chứa di vật khảo cổ. Đất có màu xám đen, độ kết dính thấp, và thành phần gồm đất giàu sét lẫn sạn sỏi tròn nhỏ. Hiện vật thu được có khá nhiều rìu bôn, phác vật, ít mảnh tước, và gốm thô;

- Tầng văn hoá chia thành hai mức: Mức thứ nhất tương ứng là lớp thứ nhất của hố một (H1) và hố hai (H2). Độ dày trung bình 20 - 40cm, kết cấu đất lẫn nhiều sạn sỏi thạch anh, ít sạn laterit, độ kết dính khá tốt, và có màu nâu nhạt hoặc vàng xám. Hiện vật đá phân bố dày đặc, gồm: Mảnh tước và phác vật có chất liệu đá opal. Di tích có nhiều vết đất cháy lẫn than tro, cụm mảnh gốm tập trung, và hố đất đen cũng xuất lộ ở lớp này. Mức thứ hai nằm ngay dưới mức văn hoá thứ nhất, không có lớp ngăn cách, và tương đương là lớp hai và ba của $\mathrm{H} 1$ và lớp hai của $H 2$. Độ dày trung bình $15-25 \mathrm{~cm}$, đất có màu nâu đỏ hoặc nâu đỏ lẫn sạn đen loang lổ, kết cấu rắn chắc, và nhiều sạn sỏi laterit hơn lớp trên. Hiện vật có phác vật công cụ, mảnh tước đá opal, đá nguyên liệu... nhưng ít dần so với mức trên. Di tích vẫn là vết tích bếp lửa cùng cụm mảnh gốm nhưng ít hơn so với lớp văn hoá thứ nhất;

- Sinh thổ là lớp đất sét đang trong quá trình bị laterit hoá, bị phong hoá từ nền đá sét kết màu nâu đỏ, đôi chỗ lẫn đốm xám đen hơi loang lồ, và kết cấu đất rắn chắc.

Nhìn chung, kết cấu tầng văn hoá giữa $\mathrm{H} 1$ và $\mathrm{H} 2$ hay ngay trong các vị trí khác nhau của cùng một hố cũng có sự khác nhau ít nhiều về độ dày cũng như thành phần cấu tạo. Nguyên nhân có thể là do hoạt động của mối hay hoạt động sản xuất cày xới san ủi và đào hố trồng cà phê của cư dân hiện đại. Lớp cư trú đầu tiên ở Chư K'tur là trên nền đất phiến sét phong hoá, thành phần tích tụ tương đối thuần, khoảng thời gian cư trú và hoạt động của con người không bị gián đoạn, và không có lớp vô sinh (Nguyễn, 2003).

Đồ gốm tìm được trong di tích rất ít và tập trung vào một vài cụm đất đen, nhiều khả năng là bếp lửa nhưng rất mờ nhạt nên không thể xác định chính xác. Chính những người khai quật, lúc đầu, cho rằng đây là tàn tích của bếp lửa, nhưng sau đó, lại cho rằng đây là vết tích liên quan đến mộ táng (?), song không thấy di cốt người và đồ tùy táng (Nguyễn, 2003, tr.9). Trong hố khai quật Chư K'tur còn có vết tích hố đất đen, có 
thể là lỗ chân cột của dạng kiến trúc lán trại nguyên thủy phục vụ cho những người thủ công chế tác công cụ̣. Bởi vì, gần vết tích lỗ chân cột là nơi tập trung các đống phế liệu nhiều nhất, hiện tượng này cũng thấy ở di tích cư trú - xưởng Thôn Bốn (Lâm Đồng).

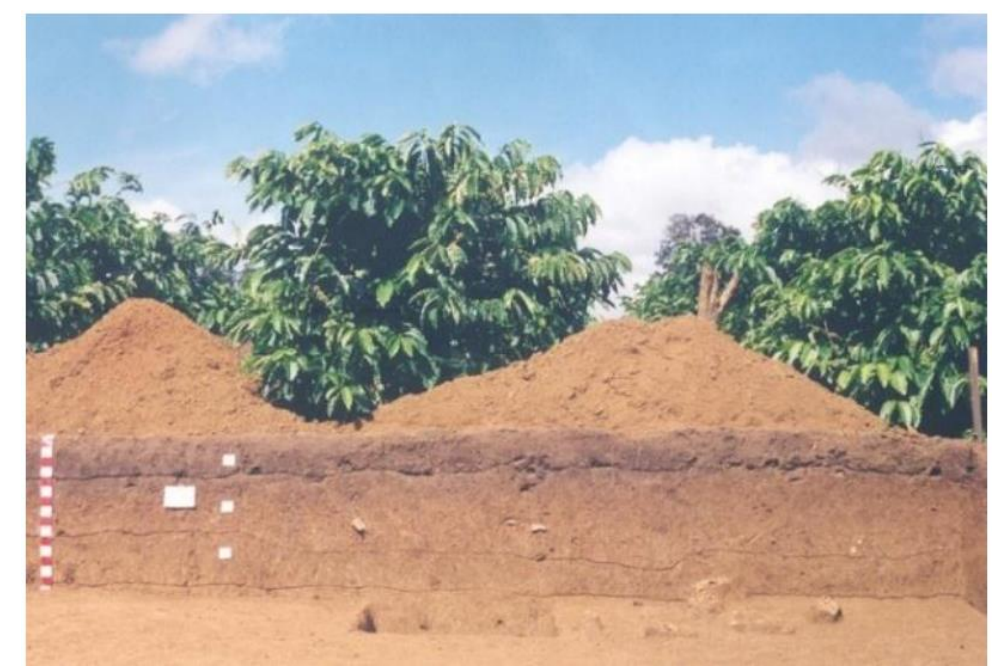

Hình 3. Địa tầng hố một, vách Tây - Bắc, di tích Chư K'tur (Đắk Lắk)

Nguồn: Lê (2015).

\subsubsection{Di tích Buôn Kiều}

Di tích Buôn Kiều ở địa phận Buôn Kiều, xã Yang Mao, huyện Krông Bông (Đắk Lắk) được khai quật vào năm 2015 với địa tầng dày $60-70 \mathrm{~cm}$ (Nguyễn, 2015). Hai hố khai quật có kết cấu địa tầng khá đồng nhất về cấu tạo cũng như phân bố hiện vật:

- Hố một (15.BK.H1) được mở ở triền gò thấp cách nhà cộng đồng Buôn Kiều $2.7 \mathrm{~m}$ về hướng bắc, tọa độ địa lý là $12^{0} 25^{\prime} 161^{\prime \prime}$ vĩ Bắc và $108^{0} 33^{\prime} 578^{\prime}$ " kinh Đông. Tổng diện tích khai quật là $55 \mathrm{~m}^{2}(11 \mathrm{~m} \times 5 \mathrm{~m})$. Mặt bằng hố thoải dần từ tây sang đông do địa hình khu vực;

- Hố hai (15.BK.H2) mở cách hố một khoảng $110 \mathrm{~m}$ về phía Bắc, tọa độ địa lý là $12^{0} 25^{\prime} 189$ " vĩ Bắc và $108^{0} 34^{\prime} 002^{\prime}$ kinh Đông. Tổng diện tích hố khai quật là $12 \mathrm{~m}^{2}(3 \mathrm{~m} \times 4 \mathrm{~m})$. Mặt bằng hố hai cũng thoải dần từ tây sang đông.

Nhìn chung, lớp đất canh tác dày $5-20 \mathrm{~cm}$ và tầng văn hoá không dày lắm, trung bình $40-50 \mathrm{~cm}$. Di tích Buôn Kiều chỉ có một lớp văn hoá và địa tầng không thấy sự khác biệt đáng kể nào về thành phần và màu sắc theo độ sâu. Quá trình thành tạo tầng văn hoá ở đây chủ yếu do phế thải của các hoạt động sống, mà đặc biệt là do phế thải của việc chế tác đá. Những người khai quật cho rằng, thời gian cư trú và hoạt động của cư dân cổ tại khu vực này không quá dài, nhiều khả năng nằm trong khoảng 100 năm đến 200 năm (Nguyề̃n, 2015, tr. 7). 


\subsubsection{Di tích Thôn Tám}

Di tích Thôn Tám ở xã Đắc Wil, huyện Cư Jút (Đắk Nông) khai quật vào năm 2006 (Nguyễn \& Lê, 2007) và năm 2013 (Lê \& ctg., 2014). Địa tầng cơ bản gồm ba lớp từ trên xuống:

- Lớp mặt đất có màu xám nhạt, tơi xốp, và dày trung bình $10 \mathrm{~cm}$. Lớp đất này chứa nhiều hạt sạn sỏi cát kết, basalt phong hoá, và đã bị xáo trộn. Lẫn trong lớp mặt có khá nhiều mảnh tước, phác vật công cụ, và đá nguyên liệu;

- Tầng văn hoá là lớp đất sét màu nâu và dày $50 \mathrm{~cm}$, trong lớp này lẫn nhiều đá basalt xốp và sạn sỏi cát kết bở rời với độ kết dính yếu. Trong tầng văn hoá chứa di tích, di vật đá, và ít đồ gốm. Di tích tìm thấy trong tầng văn hoá là những cụm đá basalt có kích thước lớn và được xếp thành cụm. Cư dân tiền sử xếp những viên đá basalt xốp có kích thước to nhỏ khác nhau nhưng phổ biến là cỡ $20 \mathrm{~cm} \times 20 \mathrm{~cm}$ lẫn với các mảnh đá silic thành từng cụm. Diện tích mỗi cụm cũng khác nhau, khoảng từ $50 \mathrm{~cm}$ đến gần $100 \mathrm{~cm}$. Bên trong và xung quanh các cụm đá xếp có nhiều mảnh tước và đá nguyên liệu chế tác công cụ. Rất có thể, đây là những cụm đá xếp để ngồi hoặc dùng để kê như những chiếc đe trong khi chế tác đá;

- Sinh thổ nằm ngay dưới tầng văn hoá và không có lớp ngăn cách. Đây là lớp đất sét màu nâu sẫm, độ kết dính cao, và lẫn nhiều sạn sỏi hay những cục đá cát kết.

Di tích Thôn Tám và các địa điểm trong khu vực đầm Sương Mù và Thôn Bảy có kết cấu địa tầng thuần nhất, và chỉ có một lớp văn hoá. Các địa điểm ở đây không thấy sự khác biệt đáng kể nào về thành phần cấu tạo của tầng văn hoá. Ở nhiều chỗ, tầng văn hoá lộ ra ngay trên bề mặt do bị bào mòn hoặc xáo trộn do canh tác. Quá trình thành tạo tầng văn hoá chủ yếu do phế thải từ các hoạt động chế tác đá hay một phần do phong hoá của đất đá tại chỗ bồi tạo nên địa tầng. Những người khai quật cho rằng, thời gian cư trú và hoạt động của cư dân tiền sử nơi đây không quá dài, khả năng từ 300 năm đến 400 năm (Nguyền \& Lê, 2007). Trong di tích công xưởng Thôn Tám chưa tìm thấy dấu vết bếp lửa và không có dấu tích mộ táng.

\subsubsection{Di tích Thôn Bốn}

Di tích này ở xã Gia Lâm, Lâm Hà (Lâm Đồng) được khai quật vào năm 2006 (Trần \& Lê, 2006, tr. 2), cấu trúc địa tầng gồm ba lớp như sau (Hình 4):

- Lớp mặt dày $15-20 \mathrm{~cm}$, đất màu xám đen, và tơi xốp. Trong lớp này phát hiện khá nhiều hiện vật bị xáo trộn vào;

- Lớp văn hóa dày trung bình $30-35 \mathrm{~cm}$, đất basalt có màu nâu sẫm, lớp đất này chứa nhiều phác vật, và phế vật khảo cổ. Tầng văn hoá gần như còn nguyên vẹn (insitu), ngoại trừ những bồn đất được đào để trồng cây cà phê; 
- Sinh thổ là đất basalt có màu nâu sẫm và khá thuần. Trong tầng đất này hoàn toàn không có hiện vật hay di tích.

Trong hố khai quật ở Thôn Bốn đã tìm thấy không nhiều mảnh gốm, di tích là sự xuất hiện lỗ đất đen (lỗ chân cột?). Gần những lỗ đất đen là nơi tập trung cao mảnh phế liệu đá opal và cùng phác vật bị gãy, vỡ, và hư hỏng. Địa tầng di tích Thôn Bốn cho thấy, đây là trại chế tác công cụ mang tính tạm thời.

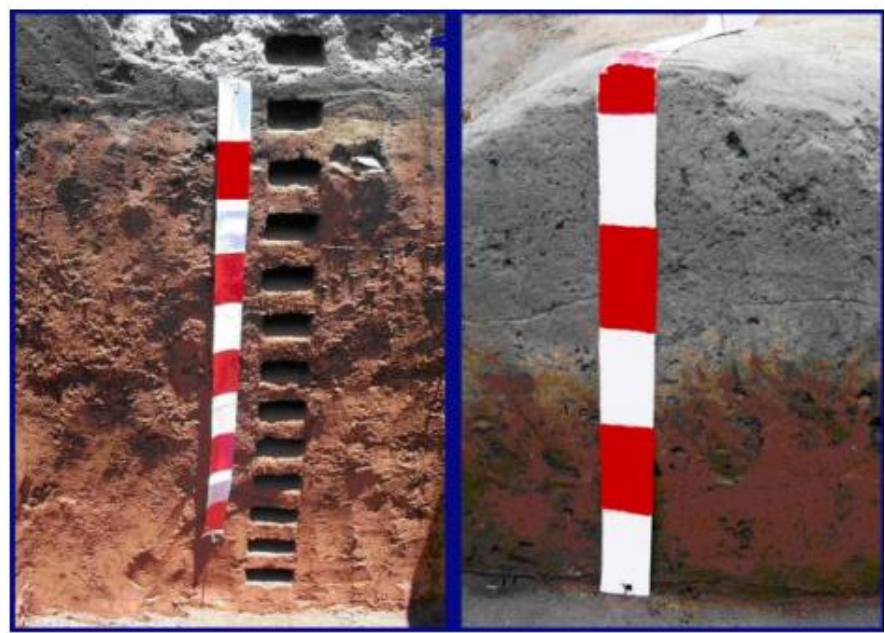

Hình 4. Địa tầng di tích Thôn Bốn (Lâm Đồng)

Nguồn: Lê (2015).

\subsubsection{Di tích Hoàn Kiếm}

Di tích này ở xã Nam Hà, Lâm Hà (Lâm Đồng) được khai quật vào năm 2008 (Bùi, 2010), cấu tạo địa tầng gồm các lớp (Hình 5):

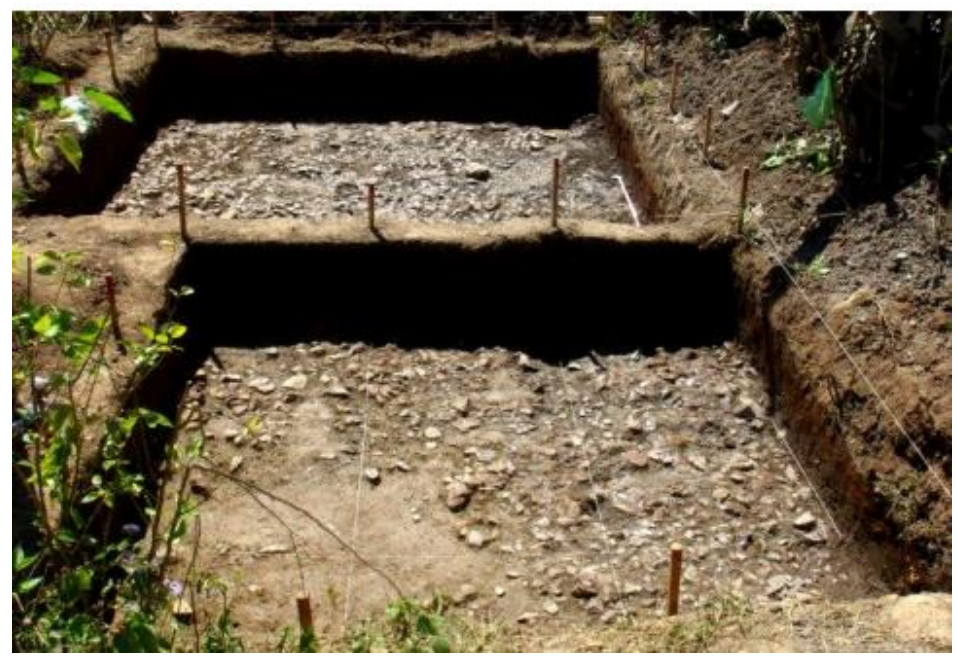

Hình 5. Bình diện hố khai quật hai, di tích Hoàn Kiếm (Lâm Đồng)

Nguồn: Lê (2015). 
- Lớp mặt gồm ba tầng đất có khác biệt nhau về màu sắc. Tầng thứ nhất dày trung bình $10-15 \mathrm{~cm}$, đất có màu xám đen, lẫn đất sét nên có độ dẻo cao, và không có di vật khảo cổ. Tầng thứ hai dày trung bình $20-25 \mathrm{~cm}$, đất có màu nâu đỏ, dẻo, loang lổ sét vàng, và lẫn ít than tro. Trong lớp này tìm thấy một số khối đá opal nhỏ và đây là lớp đất được hình thành trong quá trình bồi tụ từ các sườn đồi. Tầng thứ ba là lớp sét pha cát màu xám vàng và lốm đốm rỉ sét màu nâu nhạt. Kết cấu đất chắc và dày khoảng $10 \mathrm{~cm}$, trong lớp này phát hiện một số đá nguyên liệu và mảnh tước đá opal ở đáy lớp;

- Tầng văn hóa là lớp đất sét có màu xám trắng và dày $20-25 \mathrm{~cm}$. Trong tầng văn hoá chứa các di vật khảo cổ, như: Mảnh tước, hạch đá, phác vật công cụ, và đá nguyên liệu. Đồ gốm chỉ phát hiện được một mảnh miệng, có lẽ, là của một nồi gốm và chất liệu gốm thô.

- Sinh thổ là lớp sét màu xám, xám vàng có độ ngậm nước cao, và hoàn toàn không có di vật khảo cổ.

\subsubsection{Di tích Phúc Hưng}

Di tích Phúc Hưng ở Tân Hà, Lâm Hà (Lâm Đồng) được khai quật vào năm 2009 (Lê, 2011). Kết cấu địa tầng ở các hố thám sát và cả hai hố khai quật dày mỏng khác nhau nhưng tương đối đơn giản, gồm ba lớp:

- Lớp mặt, dày trung bình $10 \mathrm{~cm}$, là lớp đất canh tác bị xáo trộn. Mặt bằng nghiêng nhẹ theo sườn đồi và hơi lồi lõm. Trong lớp đất này chứa các di vật khảo cổ như phác vật công cụ, mảnh tước, đá nguyên liệu, hạch đá...;

- Lớp thứ hai có độ sâu 10 - 30cm, đất màu nâu sẫm, và độ liên kết cứng hơn. Cấu tạo từ đất đỏ basalt, màu nâu sẫm, rắn chắc, độ liên kết cứng, và nằm ngay dưới lớp canh tác. Hiện vật gồm: Mảnh tước, mảnh tách, phác vật/phế vật, đá nguyên liệu, và hạch đá;

- Lớp sinh thổ là đất đỏ basalt, kết cấu chặt, và rắn chắc. Trong lớp này không phát hiện di vật khảo cổ.

Địa tầng các công xưởng ở Lâm Đồng có tầng văn hóamỏng, trung bình dày $20 \mathrm{~cm}-35 \mathrm{~cm}$, đôi khi nằm ngay dưới lớp đất canh tác, do lớp mặt bị bóc mòn và rửa trôi. Chúng đều nằm gần khu khai thác đá nguyên liệu và tham dự vào việc khai thác và sơ chế ban đầu. Có những công xưởng như trường hợp di tích Phúc Hưng, do phân bố ở mặt bằng lồi lõm, nên các tích tụ văn hóa chỗ mỏng, chỗ dày chênh lệch nhau nhất định. Vào năm 2012, trong các hố thám sát được mở trên phạm vi đất rẫy nhà anh Nguyễn Hữu Phóng có chỗ tầng văn hoá dày $90-95 \mathrm{~cm}$, có thể nói đây là di tích công xưởng có tầng văn hoá dày hiện biết ở Tây Nguyên (Lê, 2013). Kết quả khai quật vào cuối năm 2009 - đầu năm 2010, lớp văn hoá dày trung bình $25 \mathrm{~cm}$ (Lê, 2011). Trường hợp di tích Phúc Hưng đã gợi ý rằng, mặt bằng nơi chế tác công cụ không phụ thuộc vào mặt bằng cư trú và đã tách khỏi nơi để mộ táng. Mặc dù các công xưởng ở Lâm Đồng có tầng văn 
hoá dày mỏng khác nhau, nhưng về cơ bản, chúng có cấu trúc đơn giản và chỉ có một lớp văn hoá. Cấu tạo địa tầng từ đất đỏ basalt, pha nhiều cát, đất màu nâu sẫm tương đổi mềm và xốp, và chứa các di vật khảo cổ. Trong tầng văn hóa còn bảo lưu các vết tích hoạt động của con người như: Phác/phế vật công cụ, công cụ mài, công cụ mảnh tước, hạch đá, mảnh tước... Trong đó, vết tích cư trú mờ nhạt và dấu vết công xưởng rất đậm nét.

Tóm lại, các di tích công xưởng chế tác công cụ đá ở Tây Nguyên có tầng văn hoá dày mỏng không đều nhau (dày từ $20 \mathrm{~cm}$ đến $95 \mathrm{~cm}$ ). Về cơ bản có ba lớp từ trên xuống dưới theo trật tự từ sớm đến muộn. Kết cấu tầng văn hoá đơn giản và giữa các lớp không có lớp ngăn cách. Trong tầng văn hoá bảo lưu các di vật khảo cổ, chủ yếu là những phế phẩm của hoạt động công xưởng, như: Phác vật gãy và vỡ hoặc bị lỗi kỹ thuật nào đẩy không thể tiếp tục chế tác nên cư dân cổ bỏ lại, đặc biệt là khối lượng mảnh tước đồ sộ trong tổng sưu tập. Ngoài ra, trong một số di tích còn phát hiện mộ táng, bếp lửa, và lỗ chân cột hay các cụm đá, là nơi các cư dân cổ ngồi ghè đẽo phác vật. Nghiên cứu địa tầng cho thấy, các di tích công xưởng ở Tây Nguyên có niên đại Toàn tân (Holocene) thuộc giai đoạn hậu kỳ Đá mới - sơ kỳ Kim khí. Trong một số di tích như: Taipêr, Làng Ngol, Thôn Bảy, Chư K'tur, Thôn Tám, Buôn Kiều, hay Phúc Hưng có tầng văn hoá tương đối dày. Phạm vi phân bố của các di tích rộng đến hàng vạn mét vuông. Cuộc sống của cư dân tiền sử định cư lâu dài và tổ chức các hoạt động thủ công chế tác đá, gốm, các ngành nghề thủ công khác, và sản xuất nông nghiệp. Những di tích này chứng tỏ rằng người tiền sử đã có cuộc sống định cư liên tục hàng trăm năm đến hàng ngàn năm.

\section{3. ĐặC TRƯNG DI VẬT TRONG CÁC CÔNG XƯởNG}

\section{1. Đặc trưng chất liệu}

Tại mỗi trung tâm hay nhóm di tích công xưởng luôn có một hay nhiều mỏ đá tự nhiên nằm lẫn trong lớp đá phun trào ở dạng các khối rời hay nguyên liệu cuội sông hay suối cạnh các công xưởng. Việc khai thác nguyên liệu phục vụ cho chế tác có nhiều thuận lợi hơn so với khai thác đá gốc dạng hầm mỏ kiểu ở châu Âu. Ở những địa điểm có nguồn nguyên liệu đá đã tìm thấy dấu vết cư dân cổ khai thác nguyên liệu và tạo phôi phác vật, điều ấy minh chứng tính bản địa của những sản phẩm làm ra từ các công xưởng. Kết quả phân tích thành phần chất liệu đá trong các mỏ và trong các sưu tập hiện vật cho biết nguyên liệu công xưởng được khai thác ở đâu và đặc tính hóa lý của nguyên liệu đá trong các công xưởng.

Để xác định đặc trưng chất liệu công cụ đá trong các công xưởng ở Tây Nguyên, nghiên cứu sử dụng kết quả phân tích thành phần thạch học của 104 mẫu đá ở các di tích công xưởng trên các địa bàn cách xa nhau, như: Gia Lai, Đắk Nông, và Lâm Đồng (riêng tînh Kon Tum, chúng tôi sử dụng kết quả phân tích thạch học ở di chỉ Lung Leng) (Nguyễn, 2005b). Cơ sở của phương pháp này là chúng tôi sử dụng cách xác định thành phần hóa học của các nguyên tố có trong mẫu vật (Weigand, Harbottle, \& Sayre, 1977), đây là phương pháp nghiên cứu hữu ích trong nghiên cứu di tích và di vật khảo cổ học hiện nay. Từ nguyên lý của Weigand và ctg. (1977) và Neff (2000) đã đưa ra hai 
cách tiếp cận trong nghiên cứu nguồn gốc cho hai nhóm đối tượng chính của khảo cổ học là các cổ vật được làm từ nguyên liệu đá và các cổ vật làm từ đất sét như đồ đất nung và gốm sứ đã đạt nhiều kết quả khả dĩ. Trong những năm gần đây, phương pháp này cũng được ứng dụng nghiên cứu những đối tượng khảo cổ học ở Việt Nam (Cao \& ctg., 2012;Lề, Trần, \& Trần, 2015; \& Trần, 2014). Phương pháp nghiên cứu này cũng được ứng dụng trong bài viết.

Dựa vào phân tích thành phần hoá học trong mẫu vật đá, nghiên cứu sử dụng biểu đồ $\mathrm{Na}_{2} \mathrm{O}+\mathrm{K}_{2} \mathrm{O}-\mathrm{SiO}_{2}$ xây dựng trên cơ sở 24,000 đá núi lửa tươi hoặc ít biến đồi để xác định nguồn gốc và phân loại chất liệu. Bên cạnh đó, nghiên cứu còn sử dụng giản đồ $\mathrm{K}_{2} \mathrm{O}-\mathrm{SiO}_{2}$ trong địa chất để phân loại đá vòng cung núi lửa (basalt $45-52 \% \mathrm{SiO}_{2}$, andesite $52-63 \% \mathrm{SiO}_{2}$, dacites $63-69 \% \mathrm{SiO}_{2}$, rhyolites $>69 \% \mathrm{SiO}_{2} \ldots$ ) và chuỗi đá núi lửa (tholeiitic, calc-alkaline, high-K calc-alkaline, và shoshonite theo hàm lượng $\mathrm{K}_{2} \mathrm{O}$ ). Kết quả việc phân tích nhóm được biểu diễn bởi các sơ đồ hình thành nhóm cho thấy thứ tự các mẫu kết nhóm với nhau và khoảng cách giữa chúng (Lê \& ctg., 2015).

Trong mỗi mẫu đá được tiến hành phân tích 24 nguyên tố. Kết quả phân tích mẫu đá tại bốn di tích trên địa bàn tỉnh Lâm Đồng cho thấy thành phần của các nguyên tố có giá trị tương đồng nhau, ít có sự khác biệt. Độ lệch chuẩn tương đối hầu hết thấp hơn $100 \%$ và có sự tương đồng về thành phần hóa học. Xử lý thống kê CA (Cluster Analysis) để phân loại thô các nhóm mẫu đá ở Lâm Đồng cho thấy bốn nhóm mẫu đá tại bốn di tích tập trung thành một nhóm lớn, sự tách biệt giữa các nhóm không rõ ràng. Khoảng chênh lệch hàm lượng là không lớn giữa các mẫu. Xử lý bằng PCA (Principal Component Analysis) cũng chỉ ra rằng cụm di tích ở Lâm Đồng trong không gian một nhóm lớn. Điều ấy minh chứng rằng toàn bộ các cụm di tích trên ở huyện Lâm Hà (Lâm Đồng) có sự liên hệ mật thiết với nhau về mặt nguồn gốc và có cùng một lịch sử hình thành trong các quá trình địa chất (Lê \& ctg., 2015).

Kết quả phân tích các mẫu đá ở Lâm Đồng, Đắk Nông và Gia Lai cùng với bảng tỷ lệ trung bình hàm lượng của ba khu vực thì nhận thấy thành phần của 24 nguyên tố trong mỗi mẫu vật đã phân tích thấp nhất trong ba khu vực là các mẫu đá ở Lâm Đồng, tiếp đến là các mẫu tại Gia Lai, và thành phần các nguyên tố lớn nhất thuộc về Đắk Nông (đặc biệt là các mẫu ở Thôn Tám) đã cho thấy sự khác biệt giữa nguồn nguyên liệu đá ở các khu vực cách xa nhau và không có mối liên hệ về mặt nguồn gốc. Trong nghiên cứu của Phạm (2006) đã chỉ ra rằng:

Dựa vào phân bố các nguyên tố, nhóm đá ở cụm di tích Lâm Đồng hầu hết là cùng một loại đá, thuộc nhóm Island Arc Tholeiite; Chất liệu chủ yếu là opal, silic và ít đá rhyolite - là một loại đá magma phun trào có thành phần axit (giàu điôxít silic) $\left(>69 \% \mathrm{SiO}_{2}\right)$. Kết quả nghiên cứu thành phần khoáng vật dưới kính hiển vi phân cực cũng cho một số kết quả tương tự (tr. 254-261).

Nhóm đá ở Gia Lai thuộc hai chuỗi Island Arc Tholeiite và High-K and Shoshonitic, gồm ba dòng đá chính là andesite, trachyte, và opal. Nguồn nguyên liệu có 
nguồn gốc phun trào mắc ma và phun trào núi lửa. Nguyên liệu khai thác trên bề mặt hoặc nằm trong lòng đất không sâu lắm.

Nhóm đá ở Suối Bốn (Đắk Nông) chủ yếu tập trung ở chuỗi Island Arc Tholeiite loại đá là opal và rhyolite, trừ mẫu 13.S4.ĐTr:5 là sa thạch thuộc chuỗi $H i g h-K$ and Shoshonitic - đây là nguồn đá có nguồn gốc tại địa phương. Nhóm đá ở Thôn Tám (Đắk Nông) thuộc hai chuỗi Calc-Alkaline và High-K and Shoshonitic. Loại đá ở đây khá đa dạng từ basalt, basaltic andesite, andesite, dacite, rhyolite, latite, và trachyte. Cư dân cổ Thôn Tám khai thác nguồn nguyên liệu đơn lẻ, và không khai thác đá nguyên khối để chế tác công cụ. Nguồn nguyên liệu này phân bố trên bề mặt, dọc các sông suối, ven hồ nước mà cư dân cổ đã khai thác để phục vụ hoạt động chế tác ra các công cụ.

\section{2. Đặc trưng về kỹ thuật chế tác}

Kỹ thuật chế tác công cụ đá ở Tây Nguyên chủ yếu là kỹ thuật chế tạo rìu và bôn, được xem xét trên các yếu tố kỹ thuật khai thác đá nguyên liệu, lựa chọn nguyên liệu, kỹ thuật ghè đẽo tạo phôi phác vật, kỹ thuật tu chỉnh, mài, khoan, cưa, và đánh bóng hiện vật. Trong một nghiên cứu gần đây, Le (2018) đã phác thảo khá đầy đủ về quy trình chế tác công cụ qua các công đoạn, như: Lựa chọn nguyên liệu chế tác; Khai thác nguyên liệu và sơ chế phác vật; Ghè tạo phôi và hoàn thiện phác vật; và Ghè tu chỉnh, mài hoàn thiện, và đánh bóng công cụ. Với kỹ thuật khai thác đá và lựa chọn nguyên liệu trong các công xưởng chế tác rìu và bôn đá của cư dân giai đoạn hậu kỳ Đá mới - sơ kỳ Kim khí ở Tây Nguyên có một số đặc thù riêng. Trong đó, khuynh hướng khai thác và lựa chọn đá cho chế tác rìu bôn ở Tây Nguyên chủ yểu là loại đá opal để làm rìu có vai và tứ giác, chỉ có một số ít là sử dụng đá phtanite để chế tác bôn hình răng trâu, đá basalt, chert, hoặc phiển sét silic (schist silic) làm rìu hình bầu dục. Đặc trưng kỹ thuật chế tác xem xét ở các góc độ như sau:

\subsubsection{Kỹ thuật chế tạo rìu bôn bằng đá opal}

Đá opal là loại đá có nguồn gốc núi lửa, trong suốt, và có màu vàng sáng đến đỏ hay màu mận chín (gan gà). Đá opal có độ cứng 6 đến 8 trên thang Mohs, mềm hơn nhiều loại đá quý khác, nhưng cứng hơn nhiều loại đá phổ biến như: Đá vôi (độ cứng 4) và đá basalt (độ cứng 5,5 ). Đá opal dễ ghè tách thành các mảnh lớn, cho thớ thẳng và tương đối phẳng, khi ghè thường để lại u và tia, và sóng ghè rõ ràng. Các đặc điểm trên phù hợp với việc ghè tạo phôi phác vật.

Đá opal là đá phun trào núi lửa nên ở dạng tảng cục lớn. Nguyên liệu này thường nằm sâu dưới lòng đất hoặc có trường hợp nằm ngay trên mặt đất. Mặt ngoài của đá thường bị phủ một lớp patin dày và nhiều tạp chất. Muốn có đá opal lý tưởng thì người ta phải đào đất để lấy các tảng đá lên. Phải thực hiện một vết ghè thăm dò xem cục đá này có "nạc" không, tức là ít tạp chất và có phù hợp với việc chọn làm nguyên liệu chế tác không. Ở khu vực công xưởng H'lang (Gia Lai), hay Phúc Hưng, Hoàn Kiếm (Lâm Đồng), và Suối Bốn (Đắk Nông) có rất nhiều cục đá lớn như vậy. Trong đó, nhiều cục đá có vêt ghè thử thăm dò và một số mẫu đá có chất lượng còn bỏ lại nơi khai 
thác là những viên vẫn còn khả năng được ghè đẽo vỏ phong hóa. Các tảng đá và các mảnh vỏ đá này hiện chất thành các đống ở khu vực công xưởng.

Quan sát mặt âm của các hạch đá lớn hiện còn trong các công xưởng cho biết, người tiền sử dùng kỹ thuật bổ tách lấy các mảnh đá lớn làm công cụ đơn chiếc. Đây là kỹ thuật khác với cách chế tác công cụ đá (chất liệu basalt), loại hình tứ giác hay hình chữ nhật như ở Thom Mòn (Sơn La), Cồn Chân Tiên, và Đông Khối (Thanh Hóa), hay kiểu Bình Đa (Đồng Nai). Bởi vì, các di tích này, người tiền sử tạo thanh đá dài rồi dùng cưa để tách các phôi chữ nhật nhỏ, chính là các phác vật rìu với chất liệu là đá basalt. Ở Tây Nguyên trong các công xưởng không chế tác theo kỹ thuật này.

Kỹ thuật ghè tạo phác vật rìu tứ giác trên đá opal có thể quan sát trên các công đoạn chế tác rìu đá ở công xưởng Thôn Bốn, Phúc Hưng, hay Hoàn Kiếm như sau: Người tiền sử chọn một mảnh tách/tước lớn, có độ dày cơ bản bằng độ dày rìu cần tạo ra, có mặt bụng phẳng, và mặt lưng có vài vết ghè từ hạch trước đó để làm phôi rìu. Các vết ghè được thực hiện ở hai rìa cạnh thẳng, gần song song nhau, và phần đốc thu nhỏ hơn lưỡi đôi chút. Hai rìa ở hai bên gần vuông góc với mặt bụng. Trên một đầu ghè ngang tạo đốc, đầu đối diện ghè tu chỉnh nhỏ, và vết ghè ở hai mặt tạo rìa lưỡi. Phần bụng của các di vật gần như để nguyên, phần lưng ghè nhỏ từ hai rìa lại làm cho mặt cắt ngang có hình gần tang trống. Kỹ thuật chế tạo rìu tứ giác bằng đá opal là đơn chiếc.

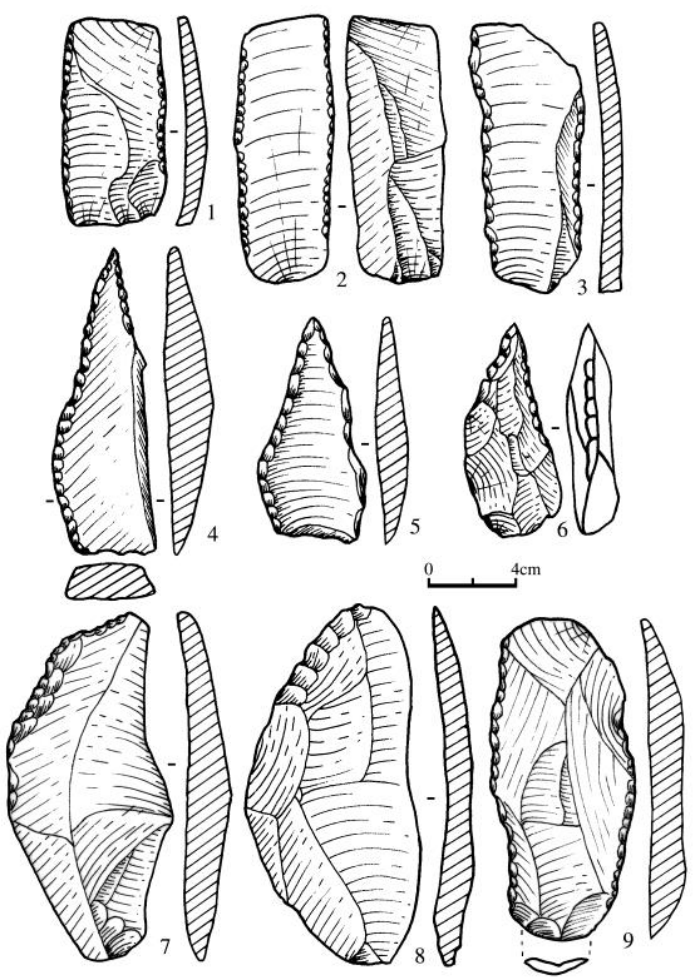

(a)
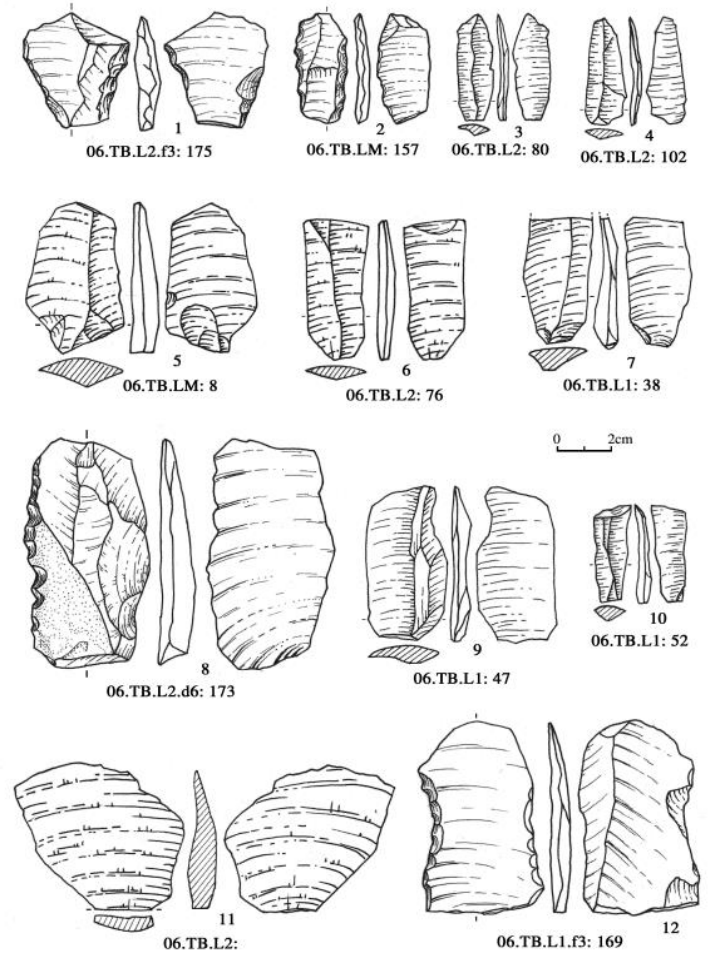

(b)

Hình 6. Công cụ mảnh tước trong các di tích công xưởng

Ghi chú: a) là công cụ mảnh tước di tích Taipêr và b) là công cụ mảnh tước Thôn Bốn.

Nguồn: Lê (2015). 
Cũng như vậy, việc chế tạo rìu có vai bằng đá opal cũng là đơn chiếc. Quan sát các chế phẩm rìu có vai ở di tích Chư K'tur (Đắk Lắk), Taipêr và H'lang (Gia Lai) có thể hình dung quy trình cơ bản như sau: Từ một mảnh tước lớn, có độ dày nhất định, người tiền sử ghè từ mặt bụng phẳng sang mặt lưng để tạo ra hai cạnh thẳng; Rìa cạnh này mở rộng hơn về phần lưỡi; Phần chuôi ghè tạo vai bởi các vết ghè theo đường chéo giữa cạnh bên và mặt đốc vào than; Hai vai rìu thường là vai xuôi (góc vai lớn hơn $90^{\circ}$ ) và để lại nhiều vết ghè nhỏ; Một chuôi nhỏ được tạo ra nằm kẹp giữa hai vai; và Một rìa lưỡi cong đều được tạo ra bằng các vết ghè hai mặt, ghè nhỏ và đều. Những chiếc bôn bằng đá opal thường có phần bụng gần như để nguyên, phẳng, và phần lưng ghè nhỏ và ngang thân vát dần về lưỡi tạo lưỡi vát lệch hẳn về một bên, mặt cắt ngang có hình gần chữ nhật và tang trống hoặc bầu dục với hai cạnh thẳng. Một số rìu có vai vuông và vai nhọn bằng đá opal còn được sử dụng kỹ thuật cưa. Dù được hỗ trợ bằng kỹ thuật cưa và mài thì việc chế tạo rìu có vai bằng đá opal vẫn là đơn chiếc. Ngoài ra, trong các công xưởng còn phát hiện khác nhiều loại hình công cụ mảnh và được chế tác từ các mảnh tước hay phiến tước mỏng chất liệu đá opal. Kỹ thuật chế tác của các công cụ này là tu chỉnh ép với các vết ghè nhỏ đến rất nhỏ tạo ra những dao/nạo sắc bén (Hình 6).

Kỹ thuật mài và đánh bóng trong chế tác rìu đá opal của cư dân tiền sử Tây Nguyên thường là những chiếc rìu có kích thước nhỏ, được ghè với những nhát ghè nhỏ và đều đặn, tạo ra được những công cụ có dáng cân đối và gần hoàn chỉnh. Đôi khi công cụ tạo ra tưởng như đã mài rồi vì bản thân đá opal nhẵn, việc mài thực chất là chỉ xóa đi các vết ghè nhỏ và rất nhỏ trên thân công cụ mà thôi. Với phác vật chưa mài cũng có thể quan sát thấy độ bóng của vết ghè trên công cụ. Sau khi mài, bề mặt công cụ bị phá hủy và trở nên đục do các vết xước khi cọ sát. Những công cụ có vết bóng sau mài trên đá opal là qua kỹ thuật đánh bóng. Cách sử dụng bàn mài và chất liệu bàn mài khác nhau cho thấy bàn mài được sử dụng cho các đối tượng khác nhau. Có những bàn mài phẳng vầ diện mài rộng, có thể mài phá và mài bề mặt công cụ. Có loại bàn mài mà vết mài chỉ ở rìa cạnh cho thấy nó có thể dùng mài phần lõm của vai rìu. Có khá nhiều bàn mài vết mài lõm hình lòng máng chạy dài, đặt vừa khít mặt lưng của rìu bôn có vai, là bàn mài rìa lưỡi công cụ. Thêm nữa, nghiên cứu nhóm bàn mài cho thấy, nếu như ở Kon Tum và Gia Lai cư dân cổ thường sử dụng loại bàn mài nhỏ với vết mài trên nhiều mặt, phổ biến là dạng gần tròn kiểu hình đĩa và hình hộp chữ nhật hoặc hình trụ, thì ở Đắk Lắk và Đắk Nông hay Lâm Đồng là bàn mài có vết mài ở mặt lớn và cả hông bàn mài nữa. Trong một số địa điểm chế tác rìu đá opal còn sử dụng bàn mài bằng đá granite. Những đá này có độ cứng lớn hơn opal và có cạnh sắc, nên có thể tham gia như những lưỡi cưa hỗ trợ vào tu chỉnh vai, rìa cạnh công cụ, và đôi khi cả rìa lưỡi nữa.

Trong một số di tích tiền sử ở Tây Nguyên phát hiện cưa đá nhưng không phổ biến. Cưa đá thông thường được làm từ nguyên liệu sa thạch và những hạt thạch anh nhỏ với mật độ cao và cứng. Cưa đá có thể sử dụng làm vai rìu đá opal có hiệu quả.

\subsubsection{Kỹ thuật chế tác bôn hình răng trâu}

Kỹ thuật chế tác bôn hình răng trâu xem xét ở công xưởng Ia Mơr và Ia Boòng, huyện Chư Prông (Gia Lai) có một số đặc điểm khác với kỹ thuật chế tác rìu bôn tứ giác hoặc có vai bằng đá opal. Do nguyên liệu chế tạo bôn hình răng trâu là đá phtanite hay 
sét silic vốn là loại đá trầm tích ở dạng khối tảng, nằm sâu trong lòng đất, và không có vỏ phong hóa dày như opal, nên khi đưa ra khỏi lòng đất, các tảng trầm tích này tương đối mềm và dễ ghè tách. Nhưng để lâu trong điều kiện thoáng khí thì chúng sẽ khô và cứng lại. Cư dân tiền sử đã lợi dụng đặc điểm này để tạo mặt bụng cho bôn hình răng trâu. Vì vậy, mặt bụng công cụ thường phẳng và hơi lõm cong cùng phần thân có hình khối chữ nhật dài và dày, sau đó, ghè nhỏ và đều từ hai rìa cạnh lại và tạo mặt cắt ngang hình tam giác. Phần lưỡi được tạo bởi nhiều nhát ghè nhỏ và dạng phiển tước lên thân, tạo rìa lưỡi vát lệch về một mặt, từ ngang thân về lưỡi mặt cắt ngang hình nửa bầu dục. Chuôi và phần thân bôn hình răng trâu có mặt cắt ngang tam giác vê cong góc cạnh, một số chiếc được tạo vai bằng những nhát ghè nhỏ hai bên. Những chiếc bôn hình răng trâu có kích thước lớn và đa số được mài toàn thân, trên thân còn phủ một lớp patine màu trắng phấn. Một số bôn hình răng trâu chôn trong mộ chưa được mài, mặt âm các vết ghè đẽo cho thấy các vết ghè nhỏ, đều đặn, và ăn rất sâu vào mặt đá, gợi ý về một kỹ thuật ghè tu chỉnh ép đều đặn còn lưu lại trên thân phác vật.

Cũng xin nói thêm rằng, trong quá trình lao động, nhiều trường hợp công cụ đá bị mẻ ở lưỡi khiến không thể tiếp tục sử dụng nên cư dân tiền sử đã ghè đẽo lại phần tác dụng, thậm chí nhiều công cụ được ghè tạo lưỡi đến gần phần tiếp giáp với vai. Những công cụ không thể tiếp tục sửa lưỡi thì chuyển thành loại hình khác, chẳng hạn như công cụ mũi nhọn. Trên thực tế, những công cụ ghè lại lưỡi thường thấy nhất là rìu và bôn làm từ đá opal hoặc đá silic, rất ít thấy loại làm từ đá phtanite. Có lẽ, đá opal và silic vừa cứng vừa hiếm nên thoả mãn chức năng dùi, điều đó gợi ý về sự tiết kiệm công cụ làm từ đá quý và hiếm của cư dân tiền sử.

\section{3. Đặc trưng loại hình}

Các loại hình sản phẩm trong mỗi trung tâm hay nhóm công xưởng chế tác đá ở Tây Nguyên là khác nhau. Thông qua nghiên cứu các loại hình sản phẩm cho phép chúng ta tìm hiểu vị trí của các loại hình rìu bôn trong từng khu vực, tính chuyên hóa của chúng ở mỗi trung tâm, quá trình phân công lao động và quy mô, và ảnh của mỗi trung tâm trong một khu vực nhất định. Những loại hình công cụ đặc trưng từ các trung tâm/nhóm công xưởng đặc thù như sau:

\subsubsection{Trung tâm chế tác bôn hình răng trâu Ia Mơr - Làng Krông}

Tiêu biểu là các địa điểm xã Ia Mơr và di tích B'riêng xã Ia Boòng, huyện Chư Prông (Gia Lai). Các địa điểm này phân bố ở dọc sông Ia Mơr, một nhánh của sông Ia Đrăng, chạy dọc biên giới Việt Nam - Campuchia rồi đổ nước vào hệ thống sông Mê Kông. Trong đó, di chỉ Ia Mơr - Làng Krông có sản phẩm tiêu biểu là bôn răng trâu bằng đá phtanit và rìu có vai bằng đá opal (Hình 7); Địa điểm $\mathrm{B}$ 'riêng, xã Ia Boòng, huyện Chư Prông là di tích cư trú - xưởng chuyên chế tác bôn hình răng trâu.

Kết quả khai quật công xưởng Ia Mơr, năm 2008, đã thu được 21 phác vật rìu bôn hình răng trâu và rìu có vai bằng đá opal, sáu rìu và bôn mài toàn thân, 14 công cụ mảnh tước/phiến tước, 15 bàn mài, một hòn ghè, một chày, một hòn nghiền, một hạch đá, 21 đá nguyên liệu, 121 phiến tước, và 4,263 mảnh tước. Đặc trưng cơ bản của nhóm di vật đá là 
nhóm phác vật rìu và bôn có vai nhưng có ít loại hoàn thiện, chủ yếu là loại phác vật bị lỗi kỹ thuật hay gãy vỡ không thể tiếp tục chế tác nên cư dân cổ đành bỏ lại. Có lẽ, những sản phẩm đạt chuẩn đã được mang đi trao đổi hoặc chuyển sang một quy trình chế tác khác trong phạm vi trung tâm/nhóm hoặc đơn vị cư trú lân cận. Những tư liệu trên cho phép khẳng định, nơi đây là các công xưởng chế tác rìu có vai là chính và bôn hình răng trâu là thứ yếu. Nguyên liệu chế tác chủ yếu là đá phtanite, silic, và ít đá opal.

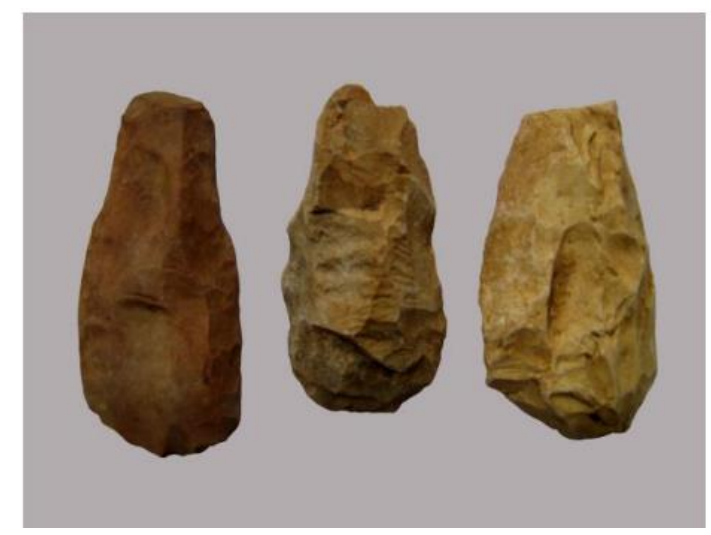

(a)

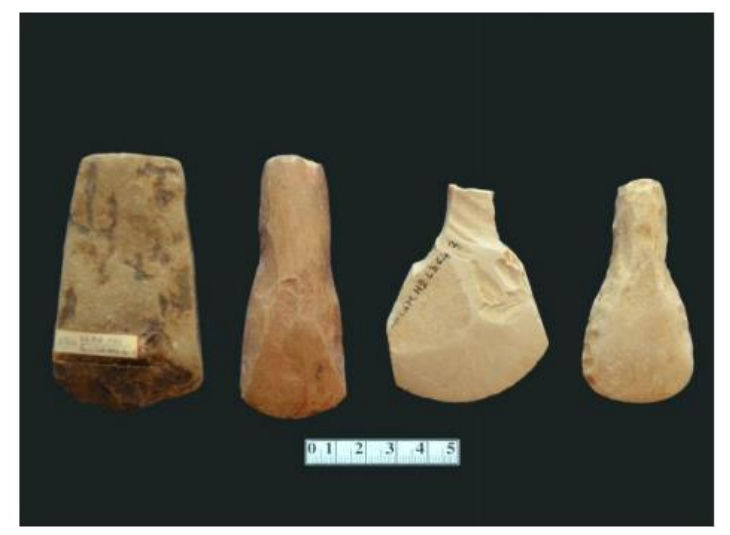

(b)

Hình 7. Phác vật và công cụ đá ở Ia Mơr - Làng Krông (Gia Lai)

Ghi chú: a) là phác vật di tích Ia Mơr, điều tra 2007 và b) là công cụ mài di tích Ia Mơr, khai quật năm 2008.

Nguồn: Lê (2015).

Công cụ mài trong các di tích Ia Mơr không nhiều, có đủ các loại hình như cuốc, rìu, và bôn nhưng có thể thấy chúng tương thích với những phác vật về hình dáng, kích thước, và chất liệu. Nhóm dụng cụ sản xuất có bàn mài, hòn ghè, và chày cũng chiếm số lượng đáng kể, bàn mài thì có loại bàn mài phẳng và mài lõm. Thống kê mảnh tước cho thấy, loại hình và kích thước mảnh tước trong di tích tương thích với những phác vật có kích thước của công xưởng, mặt âm vết ghè trên các phác vật cũng đa số nhỏ tương ứng. Những người khai quật Ia Mơr cho rằng, đồ đá giống nhau về kỹ thuật, loại hình, và chất liệu. Đây là tư liệu quan trọng để xác nhận các di tích này là một nhóm hay một cộng đồng cư dân thống nhất và ổn định (Nguyễn \& ctg., 2008).

\subsubsection{Trung tâm chế tạo rìu có vai bằng đá opal ở Chu K'tur - Taipêr}

Trung tâm chế tạo rìu có vai bằng đá opal ở Chư K'tur - Taipêr gồm các di tích công xưởng hiện biết trên địa bàn huyện Ea Kar và Ea H'leo (Đắk Lắk) và Chư Sê, Chư Pứ, và Chư Prông (Gia Lai). Trong đó, địa điểm Chư K'tur và Taipêr đóng vai trò quan trọng trong hệ thống các di tích công xưởng nơi đây. Kết quả khai quật công xưởng Chư K'tur cho thấy, tổ hợp đồ đá ở đây rất phong phú gồm nhiều loại hình từ dạng sơ chế, phác vật hoàn thiện đến đồ mài toàn thân. Trong đó, loại hình rìu bôn mài toàn thân có số lượng khá cao so với số di vật có dấu vết chế tác và sử dụng. Nguyên liệu chế tác rìu bôn là đá opal, phtanit (sét bộ kết), basalt, schist silic, sa thạch, và gỗ hóa thạch. Kết quả phân loại hiện vật theo lớp, loại hình rìu bôn mài thường phân bố ở lớp dưới, nên những người khai quật lý giải phải chăng phác vật rìu bôn bằng opal chủ 
yếu được dùng để trao đổi còn rìu bôn bằng các chất liệu khác được dùng tại chỗ, ý nghĩa như sự tiết kiệm nguyên liệu có giá trị cao như đá opal của người cổ Chư $\mathrm{K}$ 'tu (Nguyễn, 2003).

Tổng số công cụ rìu và bôn thu được là 87 tiêu bản, trong đó: Rìu và bôn có vai là 18 tiêu bản; Rìu và bôn thắt eo 30 tiêu bản; Rìu và bôn hình thang 19 tiêu bản; và Rìu và bôn không rõ hình dáng 20 tiêu bản. Tư liệu trên cho thấy, đặc trưng rìu bôn ở đây là loại có vai xuôi, rìu bôn có eo, và rìu bôn hình thang dài chuôi hẹp nhọn. Công cụ mài trong sưu tập chủ yếu có kích thước nhỏ nhắn. Điểm cần lưu ý là đồ đá ở Chư K'tur hiếm thấy loại bôn mặt cắt ngang hình chữ "D" kiểu bôn răng trâu bằng phtanit. Ở đây, chủ đạo là rìu bôn có vai xuôi hoặc có eo bằng opal và silic (Hình $8 \mathrm{a}$ ). Loại rìu bôn hình thang dài chuôi hẹp nhọn phổ biến bằng các loại đá sét bột kết và phiến sét bề mặt bị phong hoá rất giống với rìu bôn của di tích Dhap Rông (thành phố Buôn Ma Thuột) và Buôn Triết (huyện Lắk) (Trần, 2002; Trần, Nguyễn, \& Nguyễn, 2003).

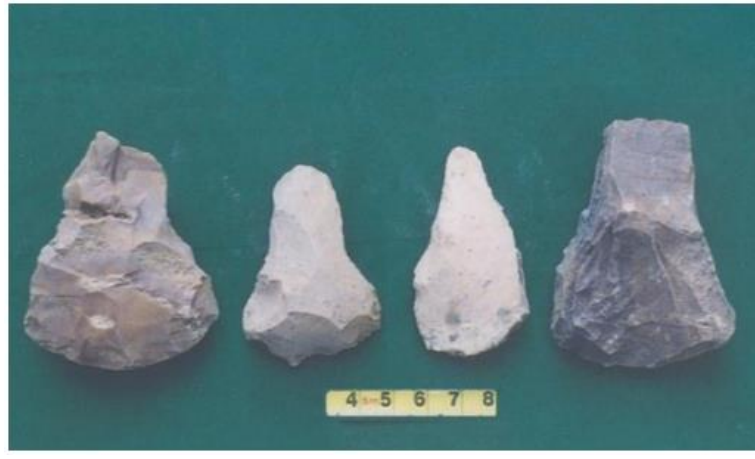

(a)

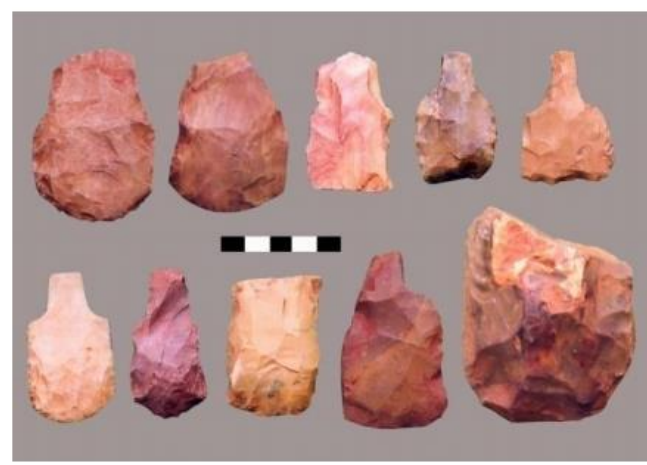

(b)

Hình 8. Phác vật rìu đá di chỉ Chư K'tur và Taipêr

Ghi chú: a) là phác vật rìu vai xuôi di tích Chư K'tur và b) là phác vật rìu bôn di tích Taipêr.

Nguồn: Lê (2015).

Đặc trưng nổi bật trong nhóm phác vật ở Chư K'tur chính là tổ hợp phác vật rìu bôn và phác vật sơ chế. Những phác vật ở Chư K’tur gần như tuyệt đối được chế tác bằng opal. Trong nhóm phác vật đã định hình rìu bôn, có một số đáng kể còn ở dạng sơ chế, và các vết ghè còn khá thô. Một số phác vật tương đối hoàn thiện nhưng trên thân vẫn còn lưu lại những vết ghè khá lớn. Trong số đó có rất nhiều tiêu bản bị một số lỗi kỹ thuật như: Vỡ/mẻ một phần chuôi hoặc lưỡi và nhiều chiếc hình dáng mất cân xứng cũng có thể bị loại bỏ. Điều này có thể lý giải rằng, di tích Chư K'tur chỉ đảm nhận khâu hoàn thiện phác vật ở dạng sơ chế rồi mang đi trao đổi ngoài cộng đồng hoặc chuyển sang công đoạn khác ở một địa điểm khác của cộng đồng. Những người khai quật cho rằng phác vật rìu bôn bằng đá opal ở Chư K'tur giống với phác vật ở di chỉ Taipêr (Hình $8 \mathrm{~b}$ ) và Làng Ngol ở huyện Chư Sê (Gia Lai). Có lẽ, phác vật rìu bôn làm từ đá opal ở các địa điểm phía nam Gia Lai và phía bắc Đắk Lắk đã được cung cấp từ các công xưởng khai thác và sơ chế phác vật ở các công xưởng trên địa bàn xã Xuân Phú huyện Ea Kar (Nguyễn, 2003). Trong đó, di chỉ Thanh Sơn và Bản Thái đóng vai trò quan trọng. 
Bàn mài cũng là loại hình hiện vật chiếm số lượng nhiều trong sưu tập đồ đá ở Chư K'tur. Bàn mài ở đây chủ yếu có chất liệu là đá sa thạch, chỉ có hai tiêu bản là gỗ hoá thạch. Về loại hình, chủ yếu là bàn mài phẳng và lõm hình lòng chảo dùng để mài rìu bôn, rất hiếm bàn mài cạnh. Chất liệu bàn mài chủ yếu là đá sa thạch (gres), số lượng thu được nhiều nhưng sản phẩm rìu mài lại rất hiếm, hầu như không có. Phải chăng, loại chất liệu này không phù hợp cho việc mài hoàn thiện công cụ có chất liệu cứng như opal hay silic. Dẫn liệu đó cũng lý giải thêm cho rìu mài hoàn thiện bằng chất liệu opal và silic không xuất hiện nhiều trong di tích. Ngoài những đặc trưng nổi trội ở trên, trong sưu tập đồ đá ở Chư K'tur còn có một tiêu bản kiếm được chế tác khá tỉ mỉ và có chuôi (kích thước tương xứng với một đoản kiếm). Tiêu bản kiếm này rất có thể mang tính quyền trượng như những thủ lĩnh thị tộc hay bộ lạc. Ngoài tiêu bản kiếm đá, bàn đập vỏ cây cũng được xem là phát hiện thú vị của di tích Chư K'tur. Bàn đập này không có chuôi mà có rãnh hình lòng máng ở hai cạnh bên để buộc kẹp làm cán cầm và loại bàn đập này đã được phát hiện ở Đắk R'lấp (Đắk Nông) (Trần, 1999). Nghiên cứu đặc trưng của sưu tập đồ đá có thể thấy công xưởng Chư K'tur và các di tích công xưởng khác trên địa bàn Đắk Lắk có yếu tố xưởng đậm nét. Vết tích cư trú mờ nhạt, đồ gốm rất ít, không có hoặc rất hiếm than tro và xương răng động vật (Nguyễn, 2003).

\subsubsection{Trung tâm chế tác rìu tú giác đá opal ở Thôn Bốn - Hoàn Kiếm}

Trung tâm chế tác rìu tứ giác đá opal ở Thôn Bốn - Hoàn Kiếm gồm các công xưởng phát hiện trên địa bàn huyện Lâm Hà. Đây là trung tâm công xưởng chuyên chế tạo rìu và cuốc tứ giác ở Tây Nguyên nói chung. Nguyên liệu chế tác gần như tuyệt đối là đá opal (hơn 90\%), còn một số dụng cụ khác ở đây được làm từ các loại đá khác như basalt, phtanite, gres, shiste, và quartzite nhưng số lượng rất ít. Những nguyên liệu này chủ yếu làm đồ trang sức, hòn ghè, hoặc bàn mài.

\section{Bảng 1. Thống kê hiện vật đá các di tích công xưởng đã khai quật ở Lâm Đồng}

\begin{tabular}{lllllllllllllll}
\hline $\begin{array}{l}\text { Di tích đã } \\
\text { khai quật }\end{array}$ & $\begin{array}{l}\text { Rìu } \\
\text { mài }\end{array}$ & $\begin{array}{l}\text { Phác } \\
\text { vật } \\
\text { rìu }\end{array}$ & $\begin{array}{l}\text { Mảnh } \\
\text { rìu } \\
\text { mài }\end{array}$ & $\begin{array}{l}\text { C.cụ } \\
\text { mảnh } \\
\text { tước }\end{array}$ & $\begin{array}{l}\text { Phác } \\
\text { vật } \\
\text { vòng }\end{array}$ & $\begin{array}{l}\text { Mảnh } \\
\text { vòng }\end{array}$ & $\begin{array}{l}\text { Đá } \\
\text { ghè } \\
\text { tròn }\end{array}$ & $\begin{array}{l}\text { Hòn } \\
\text { ghè }\end{array}$ & $\begin{array}{l}\text { Cưa } \\
\text { đá }\end{array}$ & $\begin{array}{l}\text { Bàn } \\
\text { mài }\end{array}$ & $\begin{array}{l}\text { Đá in } \\
\text { hình } \\
\text { lá cây }\end{array}$ & $\begin{array}{l}\text { Hạch } \\
\text { đá }\end{array}$ & $\begin{array}{l}\text { Tổng } \\
\text { cộng }\end{array}$ \\
\hline Thôn Bốn & 9 & 94 & 5 & 24 & 4 & 8 & 8 & 2 & 1 & 10 & 2 & 26 & 193 \\
Hoàn Kiếm & 0 & 145 & 0 & 0 & 0 & 0 & 0 & 0 & 0 & 0 & 0 & 1.587 & 1.732 \\
Phúc Hưng & 0 & 121 & 0 & 13 & 0 & 0 & 0 & 0 & 0 & 0 & 0 & 2.263 & 2.397 \\
Tổng cộng & $\mathbf{9}$ & $\mathbf{3 6 0}$ & $\mathbf{5}$ & $\mathbf{2 7}$ & $\mathbf{4}$ & $\mathbf{8}$ & $\mathbf{8}$ & $\mathbf{2}$ & $\mathbf{1}$ & $\mathbf{1 0}$ & $\mathbf{2}$ & $\mathbf{3 . 8 7 6}$ & $\mathbf{4 . 3 2 2}$ \\
\hline
\end{tabular}

Nguồn: Lê (2015, tr. 85).

Bảng 1 cho thấy, sản phẩm tiêu biểu nhất trong các di tích công xưởng Lâm Đồng là rìu và cuốc hình tứ giác (Hình 9 và Hình 10$)$. Điều này khác với các công xưởng Chư K'tur - nơi chế tác rìu có vai, công xưởng Ia Mơ và B'riêng - nơi chế tạo rìu vai xuôi và bôn rằng trâu, công xưởng Thôn Tám, Buôn Kiều, và Làng Gà - nơi chuyên chế tạo rìu hình bầu dục. Ngoài ghè đẽo, các công xưởng ở Lâm Đồng còn sử dụng kỹ thuật tu chỉnh ép và đôi khi cả kỹ thuật mài. Ở mỗi di tích tồn tại một số loại di vật đặc trưng, chẳng hạn Gan Thi 1 , Gan Thi 2, Hoàn Kiếm 1, và Phúc Hưng phác vật thường ở dạng thô, chủ yếu 
là những nhát ghè lớn, và rất ít phác vật công cụ hoàn chỉnh. Trong khi đó, các di tích ở Thôn Bốn đa số là những phác vật có kích thước nhỏ, rìa lưỡi xòe rộng hơn thân và đốc, cung lưỡi vê tròn, góc lưỡi mỏng, và vết ghè tu chỉnh ở cả hai mặt. Mặt cắt ngang thân phổ biến là hình bầu dục, hình thang, một ít là hình gần tam giác, và chữ "D" (Hình 9). Hệ thống công xưởng ở đây tồn tại tất cả các công đoạn chế tạo rìu đá từ khai thác và sơ chế nguyên liệu, ghè hoàn thiện, ghè tu chỉnh, và mài rồi sử dụng hoặc trao đổi.

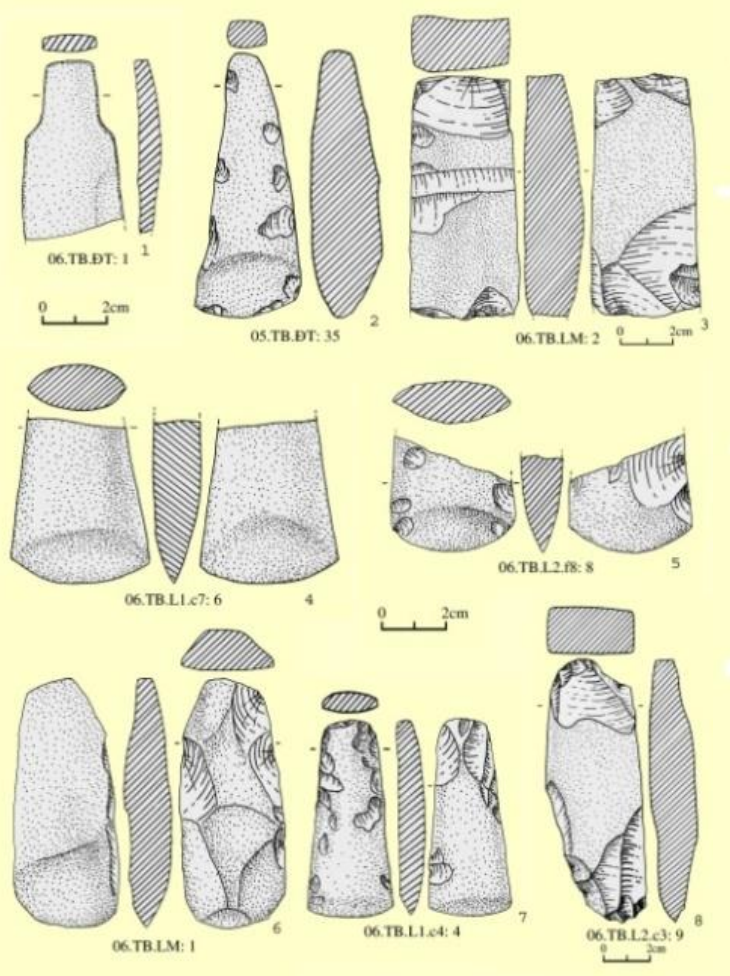

(a)

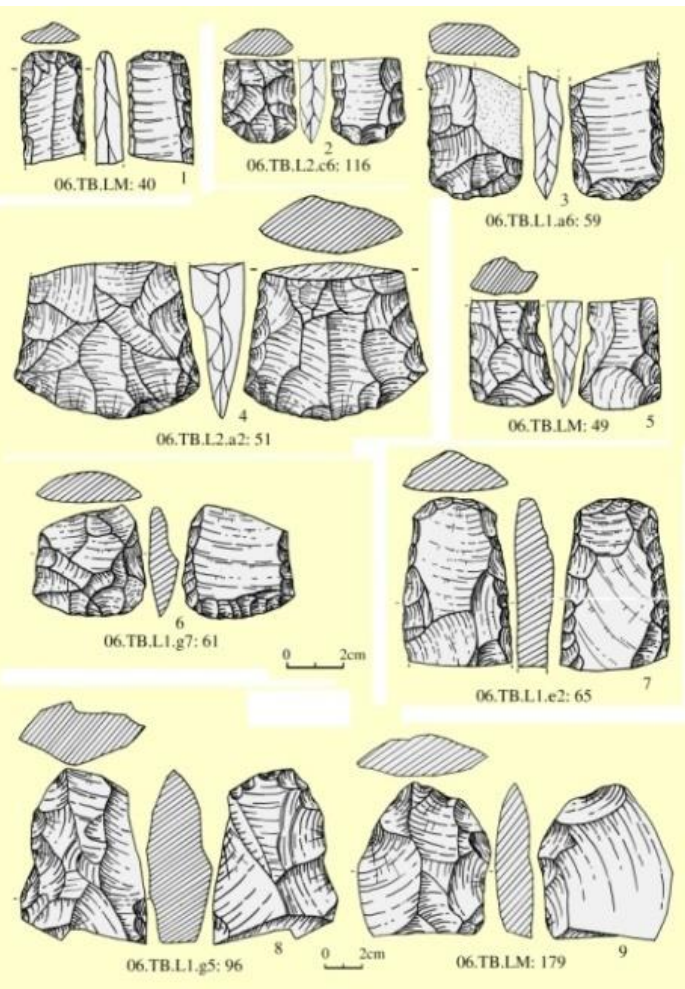

(b)

Hình 9. Đồ đá di chỉ Thôn Bốn (Lâm Đồng)

Ghi chú: a) là rìu mài và b) là phác vật rìu.

Nguồn: Lê (2015).

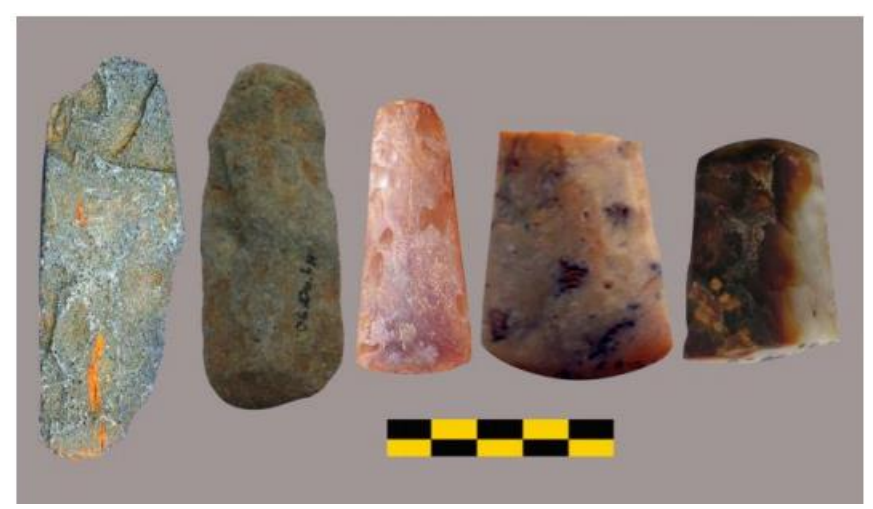

Hình 10. Rìu mài di tích Thôn Bốn (Lâm Đồng), khai quật năm 2006

Nguồn: Lê (2015). 


\subsubsection{Trung tâm công xưởng chế tác rìu có vai H'lang}

Trung tâm công xưởng chế tác rìu có vai H'lang có hơn 10 di tích hiện biết ở thượng du sông $\mathrm{Ba}$ (Gia Lai). Trong 10 di tích công xưởng hiện biết ở thượng du sông $\mathrm{Ba}$, bốn di tích Đắk Giang, Làng Róh, Soi Tre, và Tư Lương đã tìm thấy phác vật rìu nằm cùng các loại di vật khác như chày, bàn mài, hòn ghè, đồ trang sức, và đồ gốm. Trong các công xưởng này có rất ít hạch đá và đá nguyên liệu. Các di tích này vừa là nơi cư trú vừa là nơi chế tác công cụ. Còn sáu di tích khác, từ H'lang 1 đến H'lang 6 tồn tại chủ yếu là hạch đá, phác vật rìu, và mảnh tước, dấu tích cư trú lâu dài không rõ ràng. Chính vì vậy, hệ thống di tích này cần có thêm những nghiên cứu phát hiện mới để xác định mối liên hệ giữa công xưởng và đơn vị cư trú quanh khu vực.

Nhìn chung, trong các di tích công xưởng ở H'lang, di tích H'lang 2 nằm ở gần như trung tâm so với năm di tích công xưởng khác. Đây cũng là di tích còn bảo lưu đậm dấu tích khai thác nguyên liệu ban đầu. Tại đây có mặt rất nhiều viên đá opal với mặt ngoài phủ patin (phong hóa) dày và xù xì, vốn là mặt ban đầu của đá opal. Nhiều viền đá loại này hiện còn nằm sâu dưới lòng đất. Trong quá trình làm vườn, người dân (hiện đại) thu gom những viên đá này chất thành các đống ở giữa vườn hoặc xếp chúng thành hàng rào xung quanh các vườn. Trong các đống đá này, dễ dàng tìm thấy một số tảng đá có vết ghè đập. Quan sát vết đập cho thấy, có tảng đá lẫn nhiều tạp chất và hạt thô, nên bị bỏ lại. Cũng có tảng đá mịn và ít tạp chất hơn có thể sẽ tiếp tục được ghè tách mảnh. Có thể, những tảng đá có chất liệu phù hợp đã được đem đi, chỉ còn lại những mảnh không đạt tiêu chuẩn để chế tác nên bị bỏ lại (Phan, 2015).

Rõ ràng, việc khai thác nguyên liệu thời tiền sử ở đây phải đào vào lòng đất. Song các hố đào chắc chắn không sâu như kiểu hầm lò khai khoáng nguyên liệu kiểu châu Âu. Những viên đá đào lên được ghè thăm dò, nếu đạt yêu cầu thì đập nhỏ hơn, và lấy đi những cục phù hợp yêu cầu để chế tác rìu. Trên bề mặt di tích còn thấy khá nhiều đá nguyên liệu, bề mặt đá nguyên liệu có vết ghè thăm dò còn vứt lại ở di tích H'lang 2 . Có thể nói, quy mô điểm khai thác nguyên liệu ở đây rất lớn. Xung quanh H'lang 2, các di tích khác có đá nguyên liệu opal nhưng ít gặp các tảng đá to và nặng như ở H'lang 2. Rất có thể, H'lang 2 là điểm khai thác và phân phát nguyên liệu ban đầu cho các di tích công xưởng xung quanh để gia công tiếp. Trong đó, công xưởng là H'lang 3 (ở tây nam) và $\mathrm{H}^{\prime}$ lang 5 (ở tây bắc) tồn tại nhiều các hạch đá nhỏ, các mảnh tước ban đầu, nhiều mảnh tước lớn, ít phác vật hoàn thiện, và chưa tìm thấy đồ gốm. Sưu tập hiện vật ở H'lang 3 và H'lang 5 là minh chứng cho quá trình chế tạo phôi phác vật tại chỗ.

Các di tích H'lang 1 (ở phía nam), H’lang 6 (ở phía bắc), và H'lang 4 (ở phía đông) tồn tại với khối lượng rất lớn mảnh tước, trong đó mảnh tước nhỏ chiểm đa số. Ở đây, phát hiện nhiều phác vật rìu hoàn thiện hoặc gần hoàn thiện, trên thân những phác vật này có thể quan sát thấy những lỗi kỹ thuật nào đó, nên người thợ không thể tiếp tục gia công nữa và vứt lại di tích (Hình 11). Những di tích này đảm nhận công đoạn tiếp tục gia công hoàn thiện rìu và trao đổi với các cộng đồng. Sản phẩm cuối cùng là những chiếc rìu có vai. Trong các di tích này, hiện thấy ở một số gò cao, vẫn còn tập trung dày đặc mảnh tước. Có thể, đó là dấu hiệu của các nhóm nhỏ làm việc gia công hoàn thiện 
rìu đá. Điều ấy gợi ý cư dân cổ làm việc dưới các gốc cây to và trong phạm vi bóng mát của cây (Phan, 2015).

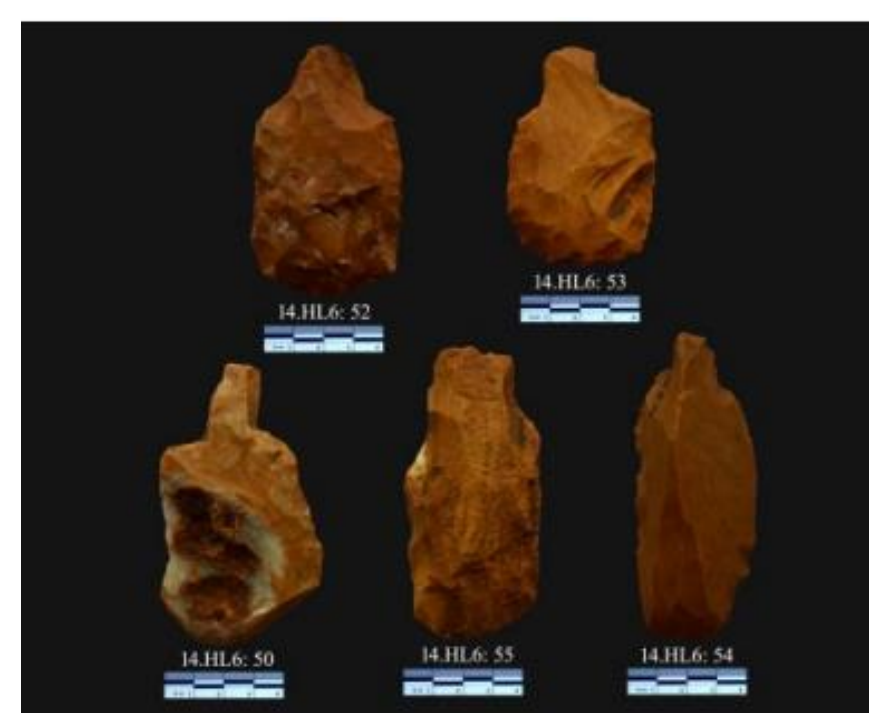

Hình 11. Phác vật rìu thám sát H'lang 1 (Gia Lai)

Nguồn: Lê (2015).

3.3.4. Các di tích chế tác rìu bầu dục, rìu mài luỡi, rìu ngắn, công cu hình đĩa...

Các di tích chế tác rìu bầu dục, rìu mài lưỡi, rìu ngắn, công cụ hình đĩa... (Hình 12) ở Gia Lai, Đắk Lắk, và Đắk Nông sử dụng nguồn nguyên liệu cuội sông và suối có ở quanh di tích. Nguyên liệu chế tác chủ yếu là đá chert, schiste silic, và basalt. Đáng chú ý, trong vài năm gần đây các nhà khảo cổ đã phát hiện và nghiên cứu các di tích trong hang động núi lửa và một số địa điểm ngoài trời ở Krông Nô (Đắk Nông) cho thấy di tích và di vật ở đây có cùng chung tính chất, đặc trưng, và niên đại với các di tích hiện biết trước đó (Lê \& ctg., 2018; Lê, Nguyễn, \& Đoàn, 2019; Lê, Phạm, \& Nguyễn, 2019; \& Nguyễn \& ctg., 2019).

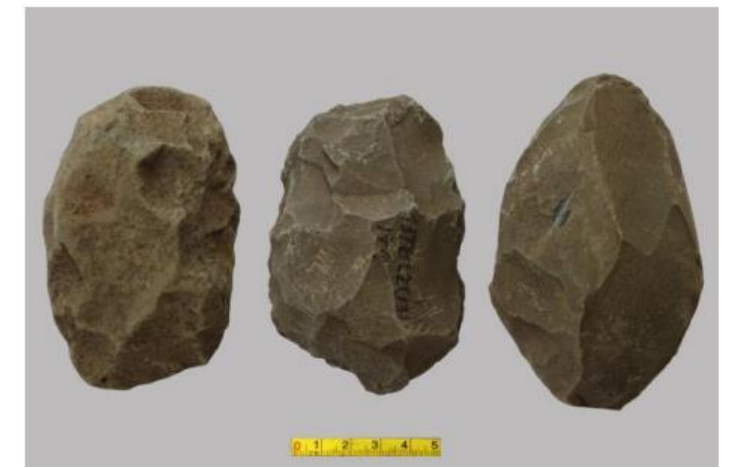

(a)

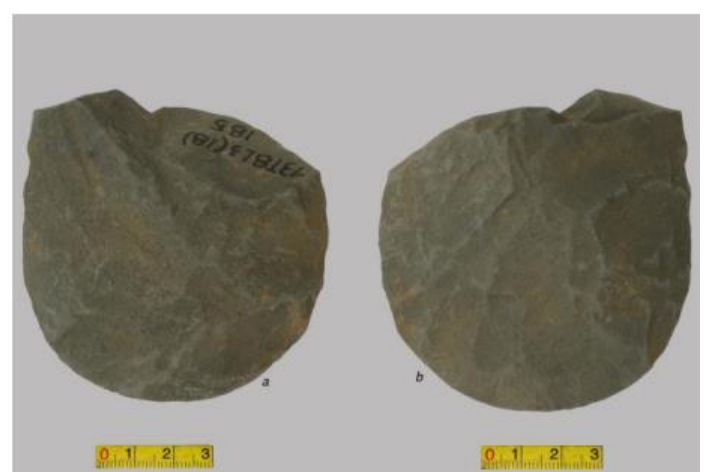

(b)

Hình 12. Phác vật và rìu mài lưỡi di chỉ Thôn Tám (Đắk Nông), khai quật năm 2013 Ghi chú: a) là phác vật di tích Thôn Tám và b) là rìu mài di tích Thôn Tám.

Nguồn: Lê (2015). 


\subsubsection{Nhóm công xương Suối Bốn}

Nhóm công xưởng Suối Bốn gồm các địa điểm phát hiện trên địa bàn xã Nhân Đạo, Đắk R'lấp (Đắk Nông). Nhóm di tích này tuy chưa tìm thấy những chế phẩm làm ra nhưng rất có thể những chiếc rìu vai xuôi và tứ giác được chế tác từ đá opal phát hiện ở Suối Ba (xã Nhân Cơ), chính là sản phẩm chế tác từ Suối Bốn. Hay, những rìu bôn tứ giác gần hình thang làm từ đá opal, thân cong khum,rìa lưỡi hơi lồi hình vòng cung, và rộng hơn đốc không nhiều phát hiện rãi rác trên địa bàn thị trấn Kiên Đức (Đắk R'lấp) là chế phẩm của nhóm công xưởng này.

\section{KẾT LUẬn}

Nghiên cứu các hoạt động thủ công chế tác công cụ đá là nghiên cứu một ngành sản xuất trong cơ cấu kinh tế xã hội tiền sử. Nghiên cứu cho thấy, các di tích công xưởng thường có địa bàn phân bố dọc các con sông, suối, hồ, và đầm thuận lợi cho việc cư trú. Những di tích công xưởng ở Tây Nguyên gắn với việc khai thác nguyên liệu và sơ chế ban đầu, ghè tu chỉnh hoàn thiện phác vật thì thường có tầng văn hóa mỏng, vết tích cư trú mờ nhạt, và hầu như không còn có chức năng mộ táng nữa. Các tư liệu nhận thấy, ngay từ khi ra đời các di tích công xưởng đã có sự chuyên hóa nhất định, phân bố thành cụm, mỗi cụm thường từ năm đến bảy địa điểm có quan hệ mật thiết với nhau trong một chuỗi quy trình chế tác công cụ đá.

Hệ thống các di tích công xưởng chế tác đá ở Tây Nguyên có địa tầng dày mỏng khác nhau, bảo lưu dấu vết công xưởng đậm nhạt khác nhau. Những di tích có tầng văn hoá dày thường nằm trong di tích cư trú - xưởng với dấu tích của bếp, than tro, và đôi khi còn có mộ táng. Tính đa loại hình và chức năng trong các di tích công xưởng ở Tây Nguyên là đặc trưng đáng chú ý. Tuy nhiên, hoạt động chế tác công cụ đá cũng có sự tách rời một cách tương đối giữa di chỉ cư trú với di tích công xưởng chế tác công cụrìu bôn bằngđá lửa và đá opal.

Giai đoạn hậu kỳ Đá mới - sơ kỳ Kim khí, ở Tây Nguyên đồng loạt ra đời các công xưởng chế tác công cụ đá và hình thành các trung tâm công xưởng. Ngoài những nét chung, ở mỗi trung tâm lại tạo ra những sắc thái riêng mang tính vùng. Trong bốn trung tâm lớn kể trên, ở mỗi trung tâm lại có sự chuyên hoá theo từng công đoạn chế tác công cụ, mỗi địa điểm đảm nhận một hoặc hai công đoạn trong quy trình chế tác. Điều đó cho thấy, vào giai đoạn hậu kỳ Đá Mới - sơ kỳ Kim khí, ở Tây Nguyên đã có sự phân công lao động mà sự phân công ấy đã vượt ra khỏi bộ tộc và vươn tới các bộ tộc liền kề. Đây là các yếu tố tích cực và có tác động đến sự phát triển sản xuất. Quan trọng hơn, các hoạt động ở công xưởng tạo nên sự thống nhất trong đa dạng về văn hoá của các cộng đồng cư dân tiền sử ở Tây Nguyên.

Về niên đại, các công xưởng chế tác công cụ đá ở Tây Nguyên có hai giai đoạn: Giai đoạn sớm gồm các di tích chế tác rìu hình bầu dục, rìu mài lưỡi, rìu ngắn, và hình đĩa kiểu Hòa Bình như trong lớp sớm di chỉ Thôn Tám, Buôn Kiều, Làng Gà, và hang C6-1 thuộc trung kỳ đá mới, có niên đại 7,000BP - 4,500BP; Các di tích công xưởng 
chế tác rìu tứ giác, bôn răng trâu, và rìu có vai tuổi muộn hơn thuộc giai đoạn hậu kỳ Đá mới - sơ kỳ Kim khí, niên đại khoảng 4,500BP - 2,500BP (Lê, 2015; \& Lê, 2019b).

Tư liệu nghiên cứu về hệ thống các di tích công xưởng ở Tây Nguyên nói riêng và trên cả nước nói chung là cơ sở dữ liệu quan trọng để đánh giá sự thống nhất trong đa dạng về văn hoá của tiểu vùng và toàn vùng. Theo đó, trong nhiều công trình nghiên cứu về tiền sử Tây Nguyên các tác giả thống nhất rằng, bước vào giai đoạn hậu kỳ Đá mới sơ kỳ Kim khí là giai đoạn lan toả và hội nhập văn hoá, các văn hoá tiền sử ở Tây Nguyên được hình thành và tạo ra cho mình những sắc thái riêng nhưng thống nhất trong đa dạng - đó là sự xuất hiện các văn hóa khảo cổ thời tiền sử ở Tây Nguyên (Lê, 2019a).

\section{TÀI LIỆU THAM KHẢO}

Bùi, C. H. (2010). Di chỉ khảo cổ học Hoàn Kiếm (Lâm Đồng). Tạp chí Khảo cổ học, (5), $35-49$.

Bùi, V. L., \& Hà, H. N. (2002). Kết quả khai quật khảo cổ học lần thứ 1 di chỉ Thôn Bảy, Chur Prông, Gia Lai. Hà Nội, Việt Nam: Viện Khảo cổ học.

Bùi, V. L., Nguyễn, G. Đ., \& Mai, T. C. (2004). Khai quật di chỉ Làng Ngol - Gia Lai. Hà Nội, Việt Nam: Viện Khảo cổ học.

Cao, Đ. V. (2012). Nghiên cưu nguồn gốc di vật đất nung khu di tích Cát Tiên bằng phuơng pháp phân tích kích hoạt hạt nhân và thống kê đa biến. Lâm Đồng, Việt Nam: Viện Nghiên cứu Hạt nhân Đà Lạt.

Lê, H. Đ. (2014). Kết quả so bộ khai quật lần thứ hai di chỉ Thôn Tám (Đắk Nông). Bài báo được trình bày tại Hội nghị Những phát hiện mới về Khảo cổ học năm 2013, Hà Nôi, Việt Nam.

Lê, H. P. (2011). Khai quật công xưởng chế tác đá thời tiền sử Phúc Hưng (Lâm Đồng). Tạp chí Khảo cổ học, (4), 11-20.

Lê, X. H. (2013). Di tích công xưởng chế tác công cụ đá Phúc Hưng trong tiền sử Lâm Đồng. Tạp chí Khoa học Xã họi Tây Nguyên, (2), 43-54.

Lê, X. H. (2015). Các di tích công xương chế tác công cụ đá giai đoạn hậu kỳ Đá mới sơ kỳ Đồng thau ở Tây Nguyên (Luận án Tiến sĩ). Học viện Khoa học xã hội, Việt Nam.

Le, X. H. (2018). Stone working process for the post - new stone - early Metal Age in Lamdong province, Vietnam. The European Journal of Humanities and Social Sciences, (6), 37-43.

Lê, X. H. (2019a). Giá trị lịch sử - văn hóa các di tích công xưởng chế tác đồ đá giai đoạn Đá mới muộn ở Tây Nguyên. Tạp chí Khoa học Đại học Đà Lạt, 9(3), 55-73.

Lê, X. H. (2019b). Tính chất và niên đại của các di tích công xưởng chế tác công cụ đá giai đoạn hậu kỳ Đá mới - sơ kỳ Kim khí ở Tây Nguyên. Tạp chí Khoa họ và Công nghệ Việt Nam, 61(10B), 49-53 
Lê, X. H., La, T. P., Phạm, T. P. T., Vũ, T. Đ., \& Nguyễn, T. M. (2018). Tư liệu và nhận thức bước đầu về cuộc thám sát di tích hang núi lửa C6-1 ở Krông Nô, tỉnh Đắk Nông. Tạp chí Khoa học Đại học Đà Lạt, 8(4), 57-76.

Lê, X. H., Nguyễn, T. T., \& Đoàn, V. N. (2019). Phát hiện mới về di tích ngoài trời trong hệ thống hang động núi lửa ở Krông Nô (Đắk Nông). Bài báo được trình bày tại Hội thảo Những phát hiện mới về Khảo cổ học năm 2018, Hà Nội, Việt Nam.

Lê, X. H., Phạm, T. P. T., \& Nguyễn, T. T. (2019). Phát hiện ba di tích khảo cổ tiền sủ ngoài trời ở suối Đắk Sô (Đắk Nông). Bài báo được trình bày tại Hội nghị Những phát hiện mới về Khảo cổ học lần thứ 54, Hà Nội, Việt Nam.

Lê, X. H., Trần, N. D. Q., \& Trần, Q. T. (2015). Úng dụng phương pháp kích hoạt Neutron và thống kê đa biến trong nghiên cứu di vật đá thời tiền sử ở Tây Nguyên. Tạp chí Khảo cổ học, (3), 19-30.

Nguyễn, G. Đ. (2003). Báo cáo khai quật di chỉ Chu K'tur (Đắk Lắk). Hà Nội, Việt Nam: Viện Khảo cổ học.

Nguyễn, G. Đ., \& Lê, H. Đ. (2007). Báo cáo khai quật di chỉ Thôn Tám xã Đắk Wil, huyện Cur Jút (Đắk Nông). Hà Nội, Việt Nam: Viện Khảo cổ học.

Nguyễn, K. S. (2005a). Báo cáo khai quật di chỉ Lung Leng, xã Sa Bình, Sa Thầy (Kon Tum). Hà Nội, Việt Nam: Viện Khảo cổ học.

Nguyễn, K. S. (2005b). Di chỉ Lung Leng, nhận thức bước đầu. Tạp chí Khảo cổ học, (5), 3-14.

Nguyễn, K. S. (2007). Khảo cổ học tiền sủ Tây Nguyên. Hà Nội, Việt Nam: NXB. Giáo dục.

Nguyễn, K. S., Lê, H. Đ., Nguyễn, G. Đ., Nguyễn, T. Đ., \& Phan, T. T. (2014). Dấu ấn văn hoá tiền sơ sứ vùng lòng hồ Plei Krông, Kon Tum. Hà Nội, Việt Nam: NXB. Khoa học Xã hội.

Nguyễn, K. S., Lê, X. H., \& Nguyễn, T. M. (2019). Kết quả khai quật hang C6-1 (Đắk Nông) năm 2018. Bài báo được trình bày tại Hội thảo Những phát hiện mới về Khảo cổ học năm 2018, Hà Nội, Việt Nam.

Nguyễn, K. S., Nguyễn, T. Đ., \& Lê, H. Đ. (2008). Báo cáo khai quật di chỉ Ia Morr, xã Ia Mo, huyện Chu Prông (Gia Lai). Hà Nội, Việt Nam: Viện Khảo cổ học.

Nguyễn, K. S., \& Phan, T. T. (2007). Khai quật di chỉ xưởng Taipêr (Gia Lai): Tư liệu, nhận thức, và thảo luận. Tạp chí Khảo cổ học, (5), 18-30.

Nguyễn, K. S., \& Phan, T. T. (2015). Các di tích tiền sử trong hệ thống sông Mê Kông ở Tây Nguyên. Bài báo được trình bày tại Hội thảo Khảo cổ học Việt Nam - Lào Campuchia trong tiểu vùng Mê Kông, Vĩnh Phúc, Việt Nam.

Nguyễn, M. T. (2015). Báo cáo so bộ kết quả khai quật khảo cổ học di tích Buôn Kiều (xã Yang Mao, huyện Krông Bông, tỉnh Đắk Lắk). Hà Nội, Việt Nam: Bảo tàng Lịch sử Quốc gia. 
Nguyễn, V. C. (1986). Các vùng tụ nhiên Tây Nguyên. Hà Nội, Việt Nam: NXB. Khoa học và Kỹ thuật.

Neff, H. (2000). Neutron activation analysis for provenance determination. In E. Ciliberto \& G. Spoto (Eds.), Archaeology modern analytical methods in art and archaeology (pp. 81-134). New York, USA: Wiley-Interscience Publication.

Phạm, B. T., Trương, Đ. T., \& Lê, X. H. (2019). Phát hiện di tích thời tiền sủ ở Buôn Hằng $1 C$, xã Ea Uy, huyện Krông Pắk (Đắk Lắk). Bài báo được trình bày tại Hội thảo Những phát hiện mới về Khảo cổ học năm 2018, Hà Nội, Việt Nam.

Phạm, Đ. M. (2006). Úng dụng thạch hoc nghiên cứu hiện vật đá thời tiền sử - sơ sư ở Nam Bộ và vùng phụ cận. TP. Hồ Chí Minh, Việt Nam: NXB. Đại học Quốc gia TP. Hồ Chí Minh.

Phan, T. T. (2015). Báo cáo kết quả điều tra khảo cổ hoc đôi bò̀ sông Ia Meur, huyện Chu Prông, tỉnh Gia Lai - năm 2015. Hà Nội, Việt Nam: Viện Khảo cổ học.

Trần, N. D. Q. (2014). Nghiên cúu thử nghiệm nguồn gốc công cụ đá tù các di tích khảo cổ hoc tiền sủ ở Lâm Đồng. Lâm Đồng, Việt Nam: Trường Đại học Đà Lạt.

Trần, Q. T. (1999). Cụm di tích khảo cổ Đắk R'lấp và mối quan hệ của nó với các văn hóa hậu kỳ đá mói - so kỳ kim khí ở khu vục xung quanh. Bài báo được trình bày tại Hội thảo Những phát hiện mới về Khảo cổ học năm 1998, Việt Nam.

Trần, Q. T. (2002). Báo cáo kết quả khai quật di chỉ Dhăp Rông thành phố Buôn Ma Thuột, tỉnh Đắk Lắk. Hà Nội, Việt Nam: Viện Khảo cổ học.

Trần, Q. T., Nguyễn, K. S., \& Nguyễn, G. Đ. (2003). Di chỉ Dhaprông - xã Ea Buar Đắk Lắk. Bài báo được trình bày tại Hội thảo Những phát hiện mới về Khảo cổ học năm 2002, Hà Nội, Việt Nam.

Trần, V. B. (2007). Di chỉ - xưởng Thôn Bốn (Lâm Đồng) với vấn đề công xưởng chế tác đá ở Tây Nguyên. Tạp chí Khảo cổ học, (5), 31-42.

Trần, V. B., \& Lê, X. H. (2006). Báo cáo kết quả khai quật di chỉ - xuơong Thôn Bốn (Gia Lâm, Lâm Hà, Lâm Đồng). Lâm Đồng, Việt Nam: Trường Đại học Đà Lạt.

Vũ, N. B., Nguyễn, K. S., \& Đào, H. Q. (1995). Tiền sủ Gia Lai. Gia Lai, Việt Nam: Sở Văn hóa Thông tin tỉnh Gia Lai.

Weigand, P. C., Harbottle, G., \& Sayre, E. V. (1977). Turquoise sources and source analisis: Mesoamerica and the Southwestern USA Exchange Systems. In K. E. Timothy \& E. E. Jonathon (Eds.), Exchange systems in prehistory (pp. 15-34). New York, USA: Academic Press. 